\title{
Gene reactivation: a tool for the isolation of mammalian DNA methylation mutants
}

\author{
F. Gounari, ${ }^{1}$ G.R. Banks, K. Khazaie, P.A. Jeggo, and R. Holliday \\ Genetics Division, National Institute for Medical Research, Mill Hill, London NW7 1AA UK
}

\begin{abstract}
We report the isolation and characterization of a mammalian strain $(t s m)$ that has a temperature-sensitive mutation in DNA methylation. The isolation procedure was based on the observation that treatment of a CHO TK $^{-}$MT $^{-}$cell line with demethylating agents introduces up to $46 \%$ demethylation, resulting in phenotypic reversion and transcriptional activation of the thymidine kinase (TK) and metallothionein (MT) genes at frequencies ranging from $1 \%$ to $59 \%$. Seven thousand individual colonies from an EMS-mutagenized CHO TK$\mathrm{MT}^{-}$population were screened for spontaneous reversion to $\mathrm{TK}^{+}$phenotype after treatment at $39^{\circ} \mathrm{C}$. Successful isolates were subsequently examined for $\mathrm{MT}^{+}$reversion. A single clone $($tsm) was obtained that showed temperature-dependent reactivation of both TK and MT genes at frequencies of $7.2 \times 10^{-4}$ and $6 \times 10^{-4}$, respectively. The $t s m$ cells were viable at $39^{\circ} \mathrm{C}$ and showed no increased mutation frequency. Reactivation correlated with transcriptional activation of the respective genes, whereas backreversion to the $\mathrm{TK}^{-}$phenotype was associated with transcriptional inactivation. $\mathrm{TK}^{-}$backrevertants were reactivable again with demethylating agents. Although demethylation in tsm cells was not detectable by HPLC, Southern blot analysis revealed that reactivants, irrespective of their mode of generation, showed specific demethylation of both TK and MT genes. Also, after about 150 cell generations after treatment, reactivants from both temperatureinduced tsm and cells exposed to demethylating agents gained $60 \%$ and $23 \%$, respectively, in 5 -methylcytosine $(5 \mathrm{mC})$. It is proposed that the phenotype of tsm cells is due to a mutation involved in the regulation of DNA methylation. The further characterization of this and other mammalian mutants should help to clarify the physiological role of DNA methylation, as well as its regulation.
\end{abstract}

[Key Words: DNA methylation; temperature-sensitive mutant; $\mathrm{CHO}$ cells; gene reactivation; thymidine kinase; metallothionein]

Received March 16, 1987; revised version accepted September 1, 1987.

The search for a role for DNA methylation in eukaryotes has focused on hypotheses that 5-methylcytosine $(5 \mathrm{mC})$ residues in the DNA may affect the transcriptional activity of genes (Holliday and Pugh 1975; Riggs 1975). Methylated bases may regulate gene activity by modulating DNA-protein interactions, which are well known in the case of prokaryotic DNA methylation. The methylated or nonmethylated state could be faithfully transmitted through cell division by the action of a maintenance methylase, which may act on hemimethylated DNA at the replication fork, but not on nonmethylated DNA. Changes in methylation patterns, which represent either de novo methylation of previously unmethylated sites or loss of methyl groups, may introduce alterations in gene expression. Evidence that DNA methylation has a role in gene expression has come from a variety of sources. A general correlation between hypomethylation and gene activity has been demonstrated, particularly from transfection experiments (for reviews, see Doerfler 1983; Razin et al. 1984; Adams and Burdon 1985).

'Present address: European Molecular Biology Laboratory, D-9600 Heidelberg, FRG.
Although methyltransferase enzymes have been partially purified, the actual specificity and regulation of DNA methylation in eukaryotes is not yet understood. The mouse DNA methylase shows preference for hemimethylated substrate (Adams et al. 1979; Gruenbaum et al. 1982), whereas the enzyme purified from rat liver shows no specificity for the methylation state of the substrate DNA (Simon et al. 1983). The relationship of these activities to DNA maintenance or de novo methylation in vivo is far from clear.

Inhibitors of DNA methyltransferases such as 5-azacytidine (5-Aza-CR) or 5-deoxyazacytidine (5-Aza-CdR) have been used frequently to study the effect of DNA demethylation in mammalian systems. Treatment with micromolar concentrations of 5-Aza-CR induces differentiation of cells in culture and reactivation of previously inactive genes in a variety of systems (for review, see Jones 1985). Thus, growth in 5-Aza-CR has been reported to induce the reversion to normal phenotype of enzyme-deficient human (Ivarie and Morris 1986), hamster (Harris 1982, 1984a,b, 1986; Steglich et al. 1985; Jeggo and Holliday 1986; Stallings et al. 1986), rat (Ivarie and Morris 1982; Sugiyama et al. 1983; Delers et al. 1984; Goss 1984), and mouse (Compere and Palmiter 
1981, Christy and Scangos 1982, 1984; Clough et al. 1982; Nakamura and Okada 1983; Liteplo et al. 1984; DeVries et al. 1986; Hickey et al. 1986) cell lines. There are also reports of 5-Aza-CR-induced reactivation of silent retroviral genes (Groudine et al. 1981; Niwa and Suguhara 1981; Conklin et al. 1982; Searle et al. 1984). In most of these instances, phenotypic changes have been associated with detectable changes in the methylation patterns of the corresponding genes. However, since 5-Aza-CR may also affect other biological pathways ( $\mathrm{Lu}$ and Randerath 1980; Tsao et al. 1984), it is possible that demethylation is not the only explanation for the observed effects.

In an attempt to define DNA sequences involved in regulation of gene expression by methylation, cloned genes have been fully or partially methylated in vitro. These constructs were then introduced into cells, and their expression was studied. Methylation in the promoter and $5^{\prime}$ gene sequences generally led to inactivity, whereas methylation in the coding or 3' sequences had no effect on gene activity (Kruczek and Doerfler 1982; Stein et al. 1982; Busslinger et al. 1983; Langner et al. 1984; Keshet et al. 1985; Murray and Grosveld 1985). In at least two instances, the herpes simplex virus (HSV) thymidine kinase (TK) and the mouse metallothionein I (MTI) genes, methylation of the coding sequences has also been shown to be important for regulation of gene expression (Christy and Scangos 1984; Keshet et al. 1985|. It was recently reported that reactivation of the TK locus in Chinese hamster fibroblasts by MNNG is associated with demethylation of $5^{\prime}$ promoter sequences, which were, however, the only part of the gene studied in this report (Barr et al. 1986; Dobrovic, pers. comm.). Induction of MTI expression by UV irradiation is associated with extensive demethylation of the gene in mouse S49 lymphoma cells (Lieberman et al. 1983). However, it is difficult in studies using in vitro modified constructs to dissociate the direct effect of DNA methylation in gene expression from nonspecific effects.

A powerful approach for studying the biological role and regulation of DNA methylation is the isolation of mutants. In the present report a $\mathrm{CHO} \mathrm{TK}^{-} \mathrm{MT}^{-}$cell line has been used for this purpose. Chinese hamster ovary $(\mathrm{CHO})$ cells were initially isolated by Puck et al. (1958) and thereafter used extensively in somatic cell genetic studies. Although chromosomal rearrangements have occurred in these cells, the total DNA content is close to that of normal Chinese hamster genome. The large number of recessive mutants isolated from $\mathrm{CHO}$ strains suggests that they are functionally hemizygous for a large number of their genes (Siminovitch 1976). It has been demonstrated recently that several recessive mutations in $\mathrm{CHO}$ cells revert to the wild type upon treatment with demethylating agents (Harris 1984a,b; Steglich et al. 1985; Jeggo and Holliday 1986). These findings place functional hemizygosity under a different perspective since they suggest that epigenetic events might underlie stable heritable variation. Irrespective of the mechanism responsible for functional hemizygosity, $\mathrm{CHO}$ cells are particularly suitable for the isolation of mutants of mammalian cells.
We report here the isolation of a $\mathrm{CHO}$ cell line that reverts to the $\mathrm{TK}^{+} \mathrm{MT}^{+}$phenotype upon induction at $39^{\circ} \mathrm{C}$. The selection procedure was based on the observation that demethylating agents induce reversion to $\mathrm{TK}^{+}$ and $\mathrm{MT}^{+}$phenotypes, suggesting that the expression of these genes is under methylation control. Reversion was associated with transcriptional activation and specific changes in the methylation patterns of the TK and MT genes. High-frequency spontaneous backreversion to the $\mathrm{TK}^{-}$phenotype was associated with transcriptional inactivation and remethylation of the TK gene. These backrevertants could be induced to revert again to the $\mathrm{TK}^{+}$phenotype by treatment with demethylating agents. Our observations suggest that the isolated cell line has a mutation in the regulation of DNA methylation.

\section{Results}

Reactivation of TK and MT genes in CHO cells by 5 $A z a-C R$ and 5-Aza-CdR

The $\mathrm{CHO}^{-} \mathrm{TK}^{-} \mathrm{MT}^{-}$subline is a derivative of the $\mathrm{CHO}$ $\mathrm{KI}\left(\mathrm{MT}^{-}\right)$line. The spontaneous incidence of reversion to $\mathrm{TK}^{+}$in these cells is about $10^{-7}$. $5-\mathrm{Aza}-\mathrm{CdR}$ was used at concentrations ranging from 0.05 to $0.4 \mu \mathrm{g} / \mathrm{ml}$ (Creusot et al. 1982) to examine whether demethylating agents revert these cells to $\mathrm{TK}^{+}$and $\mathrm{MT}^{+}$phenotypes. The frequencies of reversion to the $\mathrm{TK}^{+}$phenotype, estimated by growth in HAT medium (Szybalski et al. 1962; Littlefield 1964), are shown in Figure 1a. Maximum TK ${ }^{+}$ reversion was observed using $0.4 \mu \mathrm{g} / \mathrm{ml} 5-\mathrm{Aza}-\mathrm{CdR}$, with a recovery period of 2 days after treatment. Under these conditions less than $20 \%$ of cells survived the treatment, but up to $28 \%$ of the surviving cells expressed the $\mathrm{TK}^{+}$phenotype. Cells treated with 5-Aza-CdR were also examined for reversion to $\mathrm{MT}^{+}$phenotype. Up to $59 \%$ of the cells surviving 5-Aza-CdR treatment expressed the $\mathrm{MT}^{+}$phenotype, as revealed by their resistance to 2 $\mu \mathrm{M} \mathrm{CdCl}_{2}$ (Fig. lb).

Reversion to the $\mathrm{TK}^{+}$phenotype was also examined after treatment with 5-Aza-CR, which is significantly less toxic. Treatment of cells for a period of $24 \mathrm{hr}$ with 5-Aza-CR induced up to $1 \%$ reversion to the $\mathrm{TK}^{+}$phenotype in a dose-dependent manner. Optimum frequencies of reversion were obtained in the range of $1-3 \mu \mathrm{g} / \mathrm{ml}$. In this concentration range, more than $80 \%$ of cells survived the treatment (data not shown).

The massive induction of reversion to $\mathrm{TK}^{+}$or $\mathrm{MT}^{+}$by demethylating agents greatly exceeds the level expected from exposure to mutagens (Roufa et al. 1973; Adair et al. 1980|. To confirm this, direct comparisons were made using the DNA-damaging agents EMS and X rays (Table 1). The mutagenesis experiments were performed using doses that allowed $10 \%$ survival $(300 \mu \mathrm{g} / \mathrm{ml}$ EMS or 500 rads $X$ rays). The mutation frequency was then assayed by selection in 6-thioguanine (6-TG) and compared to $\mathrm{TK}^{+}$reversion induced by the same treatment. EMS and $\mathrm{X}$ rays increased the level of $\mathrm{TK}^{+}$reversion by two orders of magnitude. However, this is still $10^{3}-10^{4}$ times lower than reversion induced by demethylating agents. 

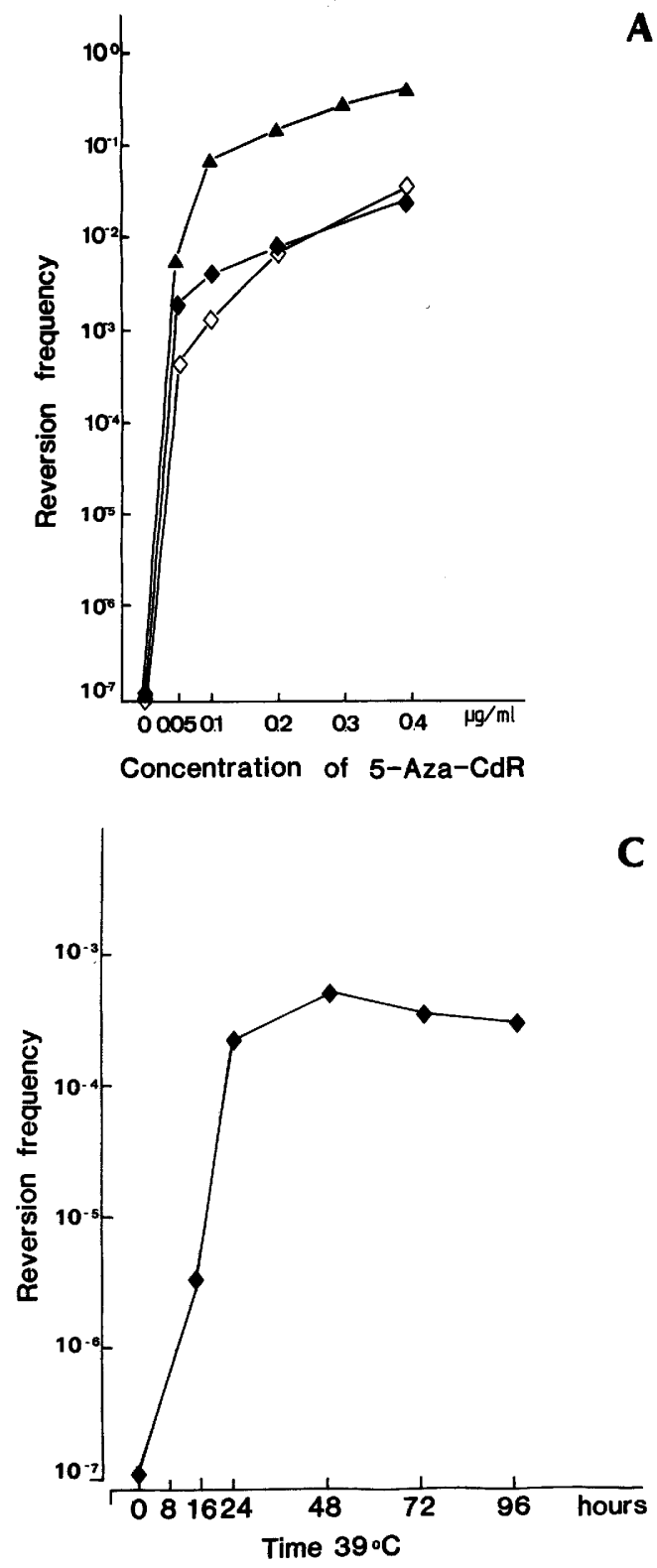

A
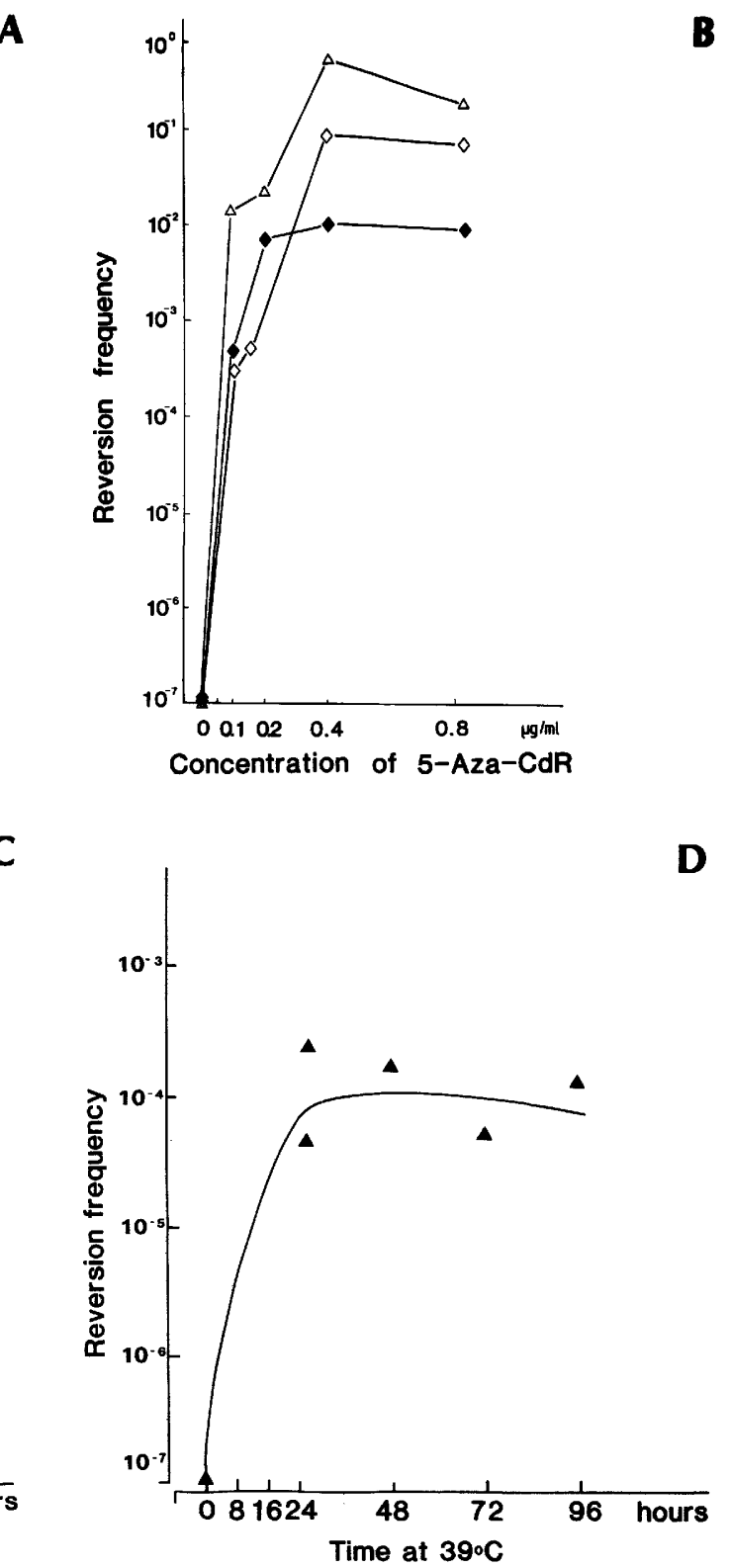

Figure 1. (A) $\mathrm{TK}^{+}$reversion induced by 5 -Aza-CdR treatment. $\mathrm{CHO} \mathrm{TK}^{-} \mathrm{MT}^{-}$cells were treated with graded concentrations of 5 -Aza-CdR from a $1 \mathrm{mg} / \mathrm{ml}$ stock solution kept in $-70^{\circ} \mathrm{C}$. After $24 \mathrm{hr}$ the cultures were rinsed with PBS and allowed to recover for 2 $(\Delta), 5(\triangle)$, and $7(\Delta)$ days before HAT selection. Each point represents the average colony count of three petri dishes seeded after treatment. $(B)$ Reversion to the $\mathrm{MT}^{+}$by 5 -Aza-CdR treatment of $\mathrm{CHO} \mathrm{TK}^{-} \mathrm{MT}^{-}$cells. $\mathrm{CHO} \mathrm{TK}^{-} \mathrm{MT}^{-}$cells were treated with graded concentrations of 5-Aza-CdR as described above. Twenty-four hours later flasks were rinsed with PBS and cells were allowed to recover in normal medium for $2(\Delta), 5|\diamond|$, and $9(\diamond)$ days. After recovery cells were plated in medium containing $2 \mathrm{~mm} \mathrm{CdCl}_{2}$ and incubated for 7-9 days. Each point represents the average colony count of three petri dishes corrected for the fraction of cells that survived treatment. (C) $\mathrm{TK}^{+}$reversion of the tsm mutant. tsm cells were treated for variable length of time at $39^{\circ} \mathrm{C}$. Reversion frequency was estimated as a function of the cells surviving the treatment. Each point represents the average reversion of three plates seeded with $10^{5}$ cells each. (D) $\mathrm{MT}^{+}$reversion of the $t s m$ mutant. $t s m$ cells were treated for variable length of time at $39^{\circ} \mathrm{C}$, and after 2 days recovery they were plated under Cd selection. Reversion frequency was estimated as a function of the cells surviving the treatment. Each point represents the average reversion of the three plates seeded with $10^{5}$ cells each. The graph presents results of two experiments.

\section{Isolation and characterization of temperature-sensitive mutants with altered DNA methylation}

If demethylation is responsible for reversion to the $\mathrm{TK}^{+}$ and $\mathrm{MT}^{+}$phenotypes, a mutant that spontaneously loses methyl groups should show high levels of rever- sion to $\mathrm{TK}^{+}$and $\mathrm{MT}^{+}$. On this basis a procedure was designed for the isolation of methylation-deficient $\mathrm{mu}$ tants. It was decided to search for mutants that reverted in a temperature-sensitive manner to the $\mathrm{TK}^{+}$phenotype and to subsequently examine these for reversion to $\mathrm{MT}^{+}$. 
Table 1. Reversion to the $T K^{+}$phenotype induced by mutagenic and nonmutagenic agents

\begin{tabular}{|c|c|c|}
\hline Treatment & $\mathrm{TK}^{+}$frequency & $\begin{array}{l}\text { Approximate } \\
\text { increase } \\
\text { in } \mathrm{TK}^{+} \text {frequency }\end{array}$ \\
\hline Spontaneous rate & $<10^{-7}$ & \\
\hline EMS $(300 \mu \mathrm{g} / \mathrm{ml})$ & $1 \times 10^{-4}-2.5 \times 10^{-5}$ & $10^{2}-10^{3}$ \\
\hline $\mathrm{X}$-rays (500 rads) & $8 \times 10^{-5}-2.5 \times 10^{-5}$ & $10^{2}-10^{3}$ \\
\hline $\begin{array}{l}\text { 5-Aza-Cr } \\
\quad(2 \mu \mathrm{g} / \mathrm{ml}) \\
\text { 5-Aza-CdR }\end{array}$ & $1.5 \times 10^{-2}-0.5 \times 10^{-2}$ & $10^{5}-10^{6}$ \\
\hline$(0.2 \mu \mathrm{g} / \mathrm{ml})$ & $2.8 \times 10^{-1}-1 \times 10^{-2}$ & $10^{6}-10^{7}$ \\
\hline
\end{tabular}

Cells were mutagenized by treatment with EMS (see Materials and methods). To eliminate $\mathrm{TK}^{+}$cells resulting directly from the mutagenesis, EMS-treated $\mathrm{CHO}^{-} \mathrm{MT}^{-}$populations were plated for single colonies in medium supplemented with BUdR. After 7-8 days of incubation at $34^{\circ} \mathrm{C}$, medium was removed, and the colonies were overlaid with $0.5 \%$ soft agar containing normal growth medium. These were left to grow for a further 2 days. Individual colonies were then transferred to replica wells in two separate 24-well plates. When the average number of cells per well was about $10^{3}$, one of each replica plate was transferred to $39^{\circ} \mathrm{C}$. After allowing $24 \mathrm{hr}$ for the expression of temperaturesensitive mutations, the test plate was returned to $34^{\circ} \mathrm{C}$ and put under HAT selection. For any well where reversion to the $\mathrm{TK}^{+}$phenotype was detected, the cells from the reference plate were isolated and subjected to quantitative studies.

Seven thousand individual colonies were screened with this procedure, and 11 preliminary isolates were obtained for the secondary screening. Two of the 11 clones proved to be true positives and were studied further. One of them showed constitutive reversion to $\mathrm{TK}^{+}$ at both temperatures with a frequency of $5 \times 10^{-5}$, but did not show detectable reversion to the $\mathrm{MT}^{+}$phenotype. The other clone expressed temperature-dependent reversion to both $\mathrm{TK}^{+}$and $\mathrm{MT}^{+}$phenotypes at frequencies of $7.2 \times 10^{-4}$ and $6 \times 10^{-4}$ (Fig. 1c,d) and was designated tsm (temperature-sensitive methylation). Thus, the $t s m$ isolate showed reversion frequencies about $10^{3}-10^{4}$ times higher than the parental strain at $39^{\circ} \mathrm{C}$, whereas at $34^{\circ} \mathrm{C}$ there was no significant difference.

Maximum $\mathrm{TK}^{+}$or $\mathrm{MT}^{+}$reversion was obtained after 24-48 hr treatment at $39^{\circ} \mathrm{C}$, whereas no reversion was detected for treatments shorter than $16 \mathrm{hr}$ (Fig. 1c,d). These results suggest that at least one $S$ phase or cell division at $39^{\circ} \mathrm{C}$ is required for expression of the tsm phenotype. Longer exposure of the cells to high temperature did not increase the frequency of reversion.

tsm cells remained viable during 2 months of growth at $39^{\circ} \mathrm{C}$, showing that the temperature-sensitive phenotype expressed in these cells is not lethal. The doubling time of the tsm strain was $23 \mathrm{hr}$ at $34^{\circ} \mathrm{C}$, which is $5 \mathrm{hr}$ slower than the equivalent of the $\mathrm{CHO}^{-} \mathrm{TK}^{-}$cells. The doubling time decreased to $16 \mathrm{hr}$ at $39^{\circ} \mathrm{C}$, but it was still 2 hr slower than that of $\mathrm{CHO} \mathrm{TK}^{-} \mathrm{MT}^{-}$cells at $39^{\circ} \mathrm{C}$. To define the initial growth response of $t s m$ at $39^{\circ} \mathrm{C}, 10^{4}$ cells were plated in each well of a multiwell plate and a growth curve was obtained at $34^{\circ} \mathrm{C}$. Then the multiwell plate was transferred to $39^{\circ} \mathrm{C}$, and estimation of the growth rate continued until cells reached confluency. The growth rate of $t s m$ cells immediately increased at the high temperature, indicating that no significant growth interruption or cell killing is caused by this treatment.

The mutability of $t s m$ cells at $39^{\circ} \mathrm{C}$ was also examined in comparison to that of the $\mathrm{CHO} \mathrm{TK}^{-} \mathrm{MT}^{-}$cell line. The mutation frequency was estimated by resistance to 6-TG (loss of HPRT activity); it was found to be $<10^{-6}$ in both cell lines, indicating that tsm does not show a significantly elevated spontaneous mutation rate.

\section{Stability of the $\mathrm{TK}^{+}$revertant phenotype}

The rate of spontaneous backreversion to the $\mathrm{TK}^{-}$phenotype by the $\mathrm{TK}^{+}$revertant clones might indicate whether the inactivation of this gene is a result of genetic or epigenetic events. The frequency of backreversion was estimated by fluctuation analysis. Ten populations from each revertant were used, and estimation of the reversion rates was based on both the method of Luria and Delbruck (1943) and its modification by Lea and Coulson (1949). $\mathrm{TK}^{+}$revertant cells induced by treatment with 5-Aza-CR and 5-Aza-CdR showed rates of spontaneous backreversion to $\mathrm{TK}^{-}$of $1.5 \times 10^{-4}$ and $5.6 \times 10^{-4}$, respectively, whereas $\mathrm{TK}^{+}$clones induced by heat treatment of the $t s m$ strain backrevert to the $\mathrm{TK}^{-}$five times less frequently $\left(6 \times 10^{-5}\right)$. The rate of backreversion in all the clones studied was about three orders of magnitude higher than the reported spontaneous mutation frequency of the TK locus in Chinese hamster cells (Roufa et al. 1973; Adair et al. 1980). The instability of $\mathrm{TK}^{+}$revertants suggests that backreversion might also be a consequence of epigenetic events. Indeed, treatment of TK- backrevertants with $1 \mu \mathrm{g} / \mathrm{ml}$ 5-Aza-CR for $24 \mathrm{hr}$ resulted again in high-frequency reversion $\left(6.2 \times 10^{-3}\right.$ to $\left.1.3 \times 10^{-2}\right)$ to the $\mathrm{TK}^{+}$phenotype. These results indicate that the phenotypic alterations studied are the result of epigenetic events.

\section{Phenotypic alterations correlate with changes in transcriptional activity of TK and MT genes}

Poly $(\mathrm{rA})^{+}$RNA was prepared from the parent $\mathrm{CHO} \mathrm{KI}$, $\mathrm{CHO} \mathrm{TK}^{-} \mathrm{MT}^{-}$and $t s m$ cell lines, $\mathrm{TK}^{+}$revertant and $\mathrm{TK}^{-}$backrevertant clones, as well as from tsm $\mathrm{MT}^{+}$revertant clones. The RNAs were separated by electrophoresis through agarose denaturing gels and blotted onto nitrocellulose filters. A Chinese hamster TK cDNA provided by Dr. J. Lewis (Lewis 1986) was used as a probe for detection of the TK transcript. A Chinese hamster cDNA MTI probe was used for detection of MT transcripts. This probe also recognizes coding sequences of the MTII transcript, which is expected to migrate with the same mobility (Griffith et al. 1983). To monitor the 
levels of RNA loaded per lane, hybridization was also performed using a hamster APRT probe.

As shown in Figure $2 \mathrm{a}, \mathrm{TK}^{+}$revertants generated either by treatment at $39^{\circ} \mathrm{C}$ or with demethylating agents show manyfold increase in the levels of TK transcript compared with parent cells. Backreversion to the TKphenotype correlates with reduction in the level of TK transcripts to that of the parent $\mathrm{CHO} \mathrm{KI}$ cells. The low levels of TK homologous mRNA in TK- cells could be due either to mitochondrial TK transcripts or to a mutated cytosolic TK mRNA. The presence of a processed TK gene has also been reported in Chinese hamster cells (Barr and Lieberman 1987).

Similarly temperature-induced reversion of tsm to $\mathrm{MT}^{+}$phenotype correlated with transcriptional induction of MT mRNA (Fig. 2b). The higher-molecularweight band in Figure $2 \mathrm{~b}$ may be an intermediate product of RNA processing. The lack of selective procedure for the $\mathrm{MT}^{-}$phenotype prevented transcriptional analysis of backrevertants.

Finally, the level of APRT transcript is not affected by the phenotype of the cells, indicating that transcriptional alterations are restricted to the TK and MT genes. These results suggest that there is a direct correlation between the phenotypic alterations described above and transcriptional activity of the TK and MT genes. Therefore, the tsm mutation is likely to affect the transcriptional regulation of at least two independent genes, TK and MT.

\section{HPLC analysis of the $5 \mathrm{mC}$ content in the CHO genome}

The results described above suggest that reversion of $\mathrm{CHO} \mathrm{TK}^{-} \mathrm{MT}^{-}$and $t s m$ cells to the $\mathrm{TK}^{+}$or $\mathrm{MT}^{+}$phenotype upon 5-Aza-CR, 5-Aza-CdR, or temperature treatment is associated with demethylation. This was examined directly by measuring the level of $5 \mathrm{mC}$ by HPLC chromatography. Up to $46 \%$ reduction in the $5 \mathrm{mC}$ level of $\mathrm{CHO}^{-} \mathrm{TK}^{-} \mathrm{MT}^{-}$cells was detected immediately after treatment with 5 -Aza-CR or 5 -Aza-CdR (Table 2). No significant remethylation was detected for the first 10 cell generations (cgs), whereas after $50 \mathrm{cgs}$ methylation nearly reached the levels before treatment. Surprisingly, $\mathrm{TK}^{+}$clones isolated from 5 -Aza-CR or 5-Aza-CdR-treated cells had significantly higher $5 \mathrm{mC}$ levels than the $\mathrm{CHO} \mathrm{TK}^{-} \mathrm{MT}^{-}$strain $150 \mathrm{cgs}$ after treatment (Table 2).

Demethylation was not detectable in DNA from tsm cells after $24-48 \mathrm{hr}$ growth at $39^{\circ} \mathrm{C}$, although because the sensitivity of the method is limited, a methylation change of only $5-10 \%$ could not be detected significantly. However, tsm $\mathrm{TK}^{+}$revertant cells induced at $39^{\circ} \mathrm{C}$ also showed a gradual increase in their $5 \mathrm{mC}$ content compared to the parent $t s m$ strain. Thus, up to $60 \%$ higher methylation was detected in these cells some 150 cgs after temperature treatment. This increase in the levels of $5 \mathrm{mC}$ could suggest that the mutation in the tsm strain might affect the overall control of DNA methylation.

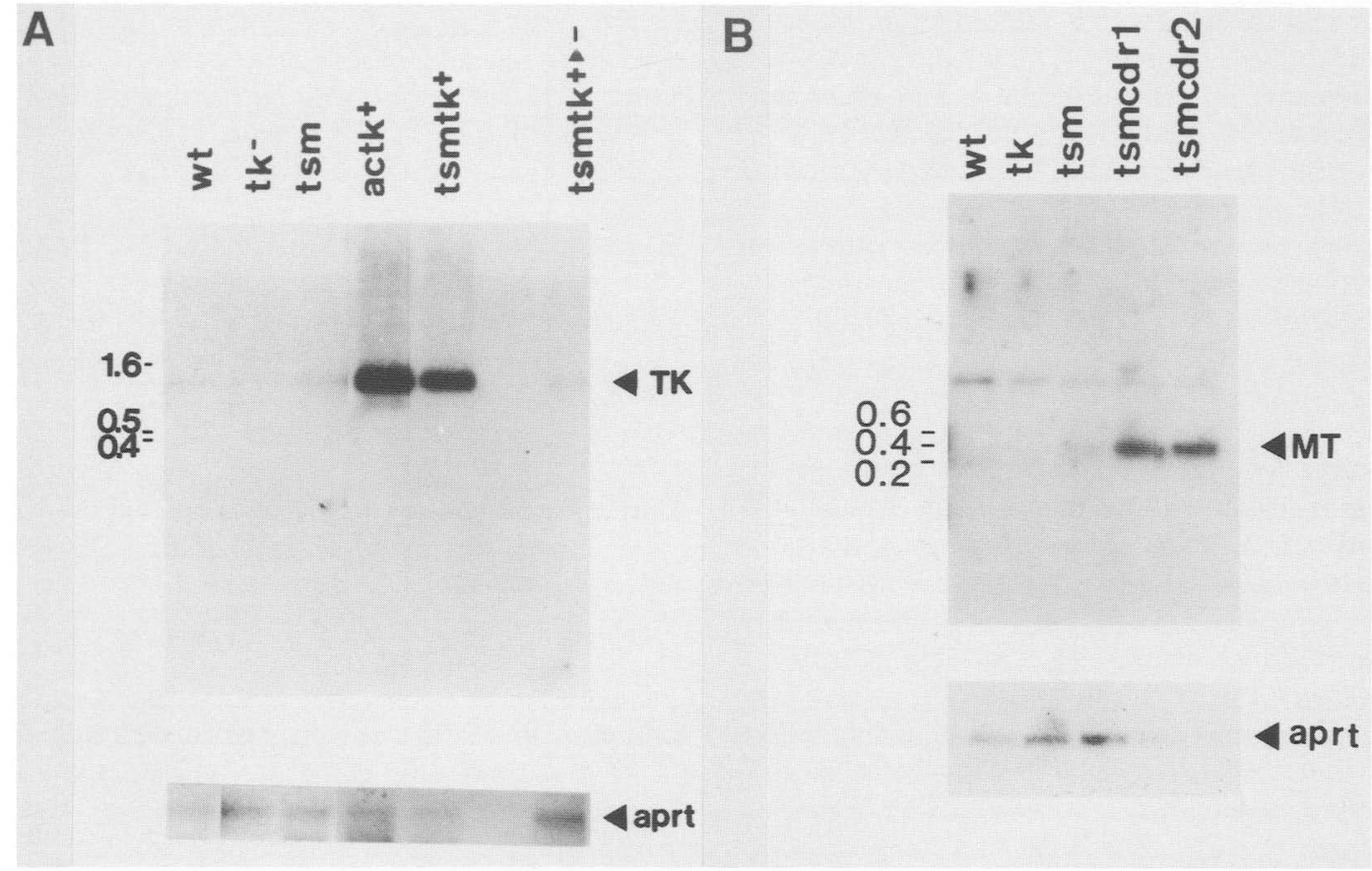

Figure 2. (A) Analysis of the TK transcript. Two micrograms per lane of poly $(\mathrm{rA})^{+} \mathrm{RNA}$ from $\left.\mathrm{CHO} \mathrm{KI}^{(\mathrm{wt})}\right)_{\mathrm{CHO}^{-}} \mathrm{TK}^{-} \mathrm{MT}^{-}\left(\mathrm{tk} \mathrm{k}^{-}\right)$, tsm, their $\mathrm{TK}^{+}$derivatives induced by either 5-Aza-CR $\left(\mathrm{actk}^{+}\right)$or heat treatment $\left(\mathrm{tsmtk}^{+}\right)$, and a tsm spontaneous backrevertant (tsmtk $\rightarrow^{-}$) were electrophoresed through a $1 \%$ agarose-formaldehyde gel. This was blotted onto nitrocellulose and hybridized against a ${ }^{32} \mathrm{P}-1$ labeled TK cDNA probe. $(B)$ Analysis of MT transcripts. Poly $(\mathrm{rA})^{+}$RNAs were prepared from $\mathrm{CHO} \mathrm{KI}_{(\mathrm{wt})}$, CHO TK ${ }^{-}$ $\mathrm{MT}^{-}\left(\mathrm{tk}^{-}\right)$and $t s m$, and two $t s m \mathrm{MT}^{+}$revertants (tsmcdrl, tsmcdr2). These were electrophoresed through a $1 \%$ denaturing agarose/ formaldehyde gel and blotted onto nitrocellulose filters. The Chinese Hamster MTI cDNA was labeled with ${ }^{32} \mathrm{P}$ and used as a probe against these filters. The amount of RNA per lane was monitored by hybridization against APRT in both $A$ and $B$. 
Table 2. The proportion of methylated cytosine in CHO KI cells and various derivatives after 5-Aza-CR or 5-Aza-CdR treatment

\begin{tabular}{|c|c|c|c|c|}
\hline \multirow[b]{2}{*}{ Strain } & \multirow[b]{2}{*}{ Treatment } & \multirow{2}{*}{$\begin{array}{l}\text { Number of } \\
\text { determinations }\end{array}$} & \multicolumn{2}{|c|}{$5 \mathrm{mC} / 5 \mathrm{mC}+\mathrm{C}(\%)$} \\
\hline & & & Range & Mean \\
\hline $\mathrm{CHO} \mathrm{KI}$ & - & 5 & $2.32-2.68$ & 2.5 \\
\hline $\mathrm{CHO}^{-} \mathrm{MT}^{-}$ & - & 4 & $2.4-2.8$ & 2.6 \\
\hline $\mathrm{CHO} \mathrm{TK}^{-} \mathrm{MT}^{-}$ & $\begin{array}{l}\text { immediately after } \\
5 \text {-Aza-CR treatment }\end{array}$ & 3 & $1.32-1.48$ & 1.4 \\
\hline $\mathrm{CHO}^{\mathrm{TK}^{-}} \mathrm{MT}^{-}$ & $\begin{array}{l}\text { immediately after } \\
5 \text {-Aza-CdR treatment }\end{array}$ & 4 & $1.41-1.45$ & 1.43 \\
\hline $\mathrm{CHO} \mathrm{TK}^{+}$ & $\begin{array}{l}\text { 5-Aza-CR followed by } \\
150 \text { cgs growth }\end{array}$ & 4 & $2.83-3.23$ & 3.03 \\
\hline $\mathrm{CHO} \mathrm{TK}^{+}$ & $\begin{array}{l}\text { 5-Aza-CdR followed by } \\
50 \text { cgs growth }\end{array}$ & 1 & 2.56 & 2.56 \\
\hline $\mathrm{CHO} \mathrm{TK}^{+}$ & $\begin{array}{l}\text { 5-Aza-CdR followed by } \\
150 \text { cgs growth }\end{array}$ & 2 & $2.96-3.46$ & 3.21 \\
\hline tsm & - & 6 & $2.6-3.0$ & 2.8 \\
\hline tsm & $24 \mathrm{hr}$ at $39^{\circ} \mathrm{C}$ & 3 & $2.55-3.05$ & 2.8 \\
\hline tsm & $48 \mathrm{hr}$ at $39^{\circ} \mathrm{C}$ & 3 & $2.51-3.01$ & 2.76 \\
\hline tsm $\mathrm{TK}^{+}$ & $\begin{array}{l}24 \mathrm{hr} \text { at } 39^{\circ} \mathrm{C} \text { followed } \\
\text { by } 50 \mathrm{cgs} \text { growth }\end{array}$ & 1 & 3.23 & 3.23 \\
\hline tsm $\mathrm{TK}^{+}$ & $\begin{array}{l}24 \mathrm{hr} \text { at } 39^{\circ} \mathrm{C} \text { followed } \\
\text { by } 150 \mathrm{cgs} \text { of growth }\end{array}$ & 2 & $4.46-4.6$ & 4.53 \\
\hline
\end{tabular}

\section{Demethylation is associated with reactivation of the} TK and MTI genes

A sensitive method for detecting alterations in the methylation pattern of specific genes is restriction analysis using methylation-inhibited enzymes. Therefore, the methylation paterns of the TK gene were studied in the $\mathrm{CHO} \mathrm{KI}$ cell line, the $\mathrm{CHO} \mathrm{TK}^{-} \mathrm{MT}^{-}$subline, the tsm strain, and their derivatives. Genomic DNAs were digested with EcoRI or HindIII, in combination with HpaII or HhaI which cleave the CCGG or GCGC sequences when the internal cytosine is unmethylated but not when methylated. Digested DNAs were electrophoresed, Southern blotted onto nitrocellulose filters, and hybridized to genomic probes covering the TK gene (Lewis et al. 1983; Lewis 1986).

The 5.5-kb fragment covering the first two exons, the promoter sequences, and approximately $2 \mathrm{~kb}$ of 5 flanking sequences (Lewis 1986) was initially used as a probe (Fig. 3a,b). Methylation changes associated with the phenotype were not deteted using the $5.5-\mathrm{kb}$ probe (Fig. 4). However, this does not eliminate the possibility that specific changes might occur within this region, since DNA fragments smaller than 300 bp created by specific demethylation would not be detectable with the sensitivity of our screening procedure. The $5.2-\mathrm{kb}$ fragment spanning the last three exons and nearly $2 \mathrm{~kb}$ of $3^{\prime}$-flanking sequences was completely methylated at HpaII and HhaI restriction sites in both TK-expressing and nonexpressing cells. Similarly, the $2.6-$ and $1.8-\mathrm{kb}$ intronic EcoRI fragments were found fully methylated for these sites both in $\mathrm{TK}^{-}$and $\mathrm{TK}^{+}$cells (results not shown).

Although no changes in the methylation status of the TK gene were detected using the above probes, hybridization with the $4.2-\mathrm{kb}$ internal fragment covering the third and fourth exons of the gene (Fig. $3 a-c$ ) revealed

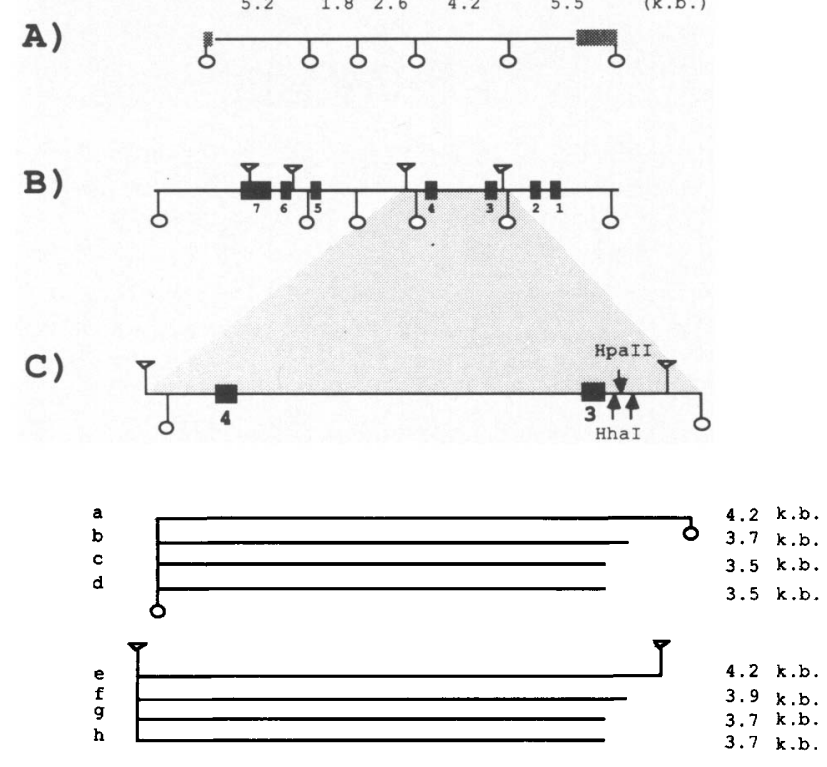

Figure 3. (A) EcoRI subclones derived from recombinant phages containing the cloned Chinese Hamster TK gene (kindly provided by Dr. John Lewis; Lewis 1986). The $3^{\prime}$ and 5' shaded boxes represent approximately $80 \mathrm{bp}$ and $2.4 \mathrm{~kb}$ of phage DNA sequences, respectively. The entire EcoRI fragments were used as probes for analysis of the methylation pattern of the TK gene. $(B)$ Restriction map of the TK gene for EcoRI (O) and HindIII $(\nabla)$ sites. Position of the outermost EcoRI sites was estimated by Barr et al. (1986). Numbered solid boxes $(1-7)$ indicate the approximate position of the exons. $(C)$ Expanded map of the EcoRI-HindIII fragment covering the third and fourth exons as well as the putative methylation regulatory region. (a-h) Fragments detected by hybridization of the 4.2-kb EcoRIEcoRI probe in EcoRI/HpaII, EcoRI/HhaI, HindIII/HpaII, and HindIII/HhaI blots of CHO DNA (Figs. 5 and 6). 


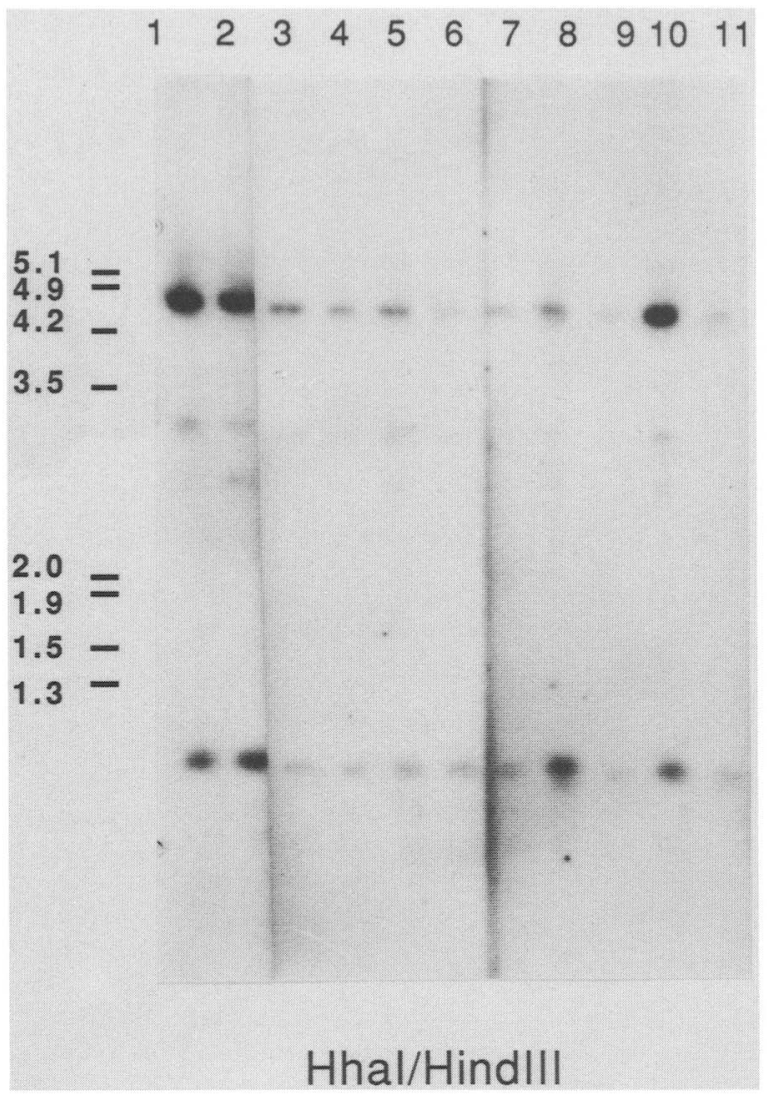

Figure 4. Methylation analysis of the $5^{\prime} \mathrm{TK}$ region in derivatives of the CHO KI cell line. DNA samples (15 $\mu \mathrm{g}$ per lane) are designated as: (1) $\mathrm{TK}^{+} \mathrm{CHO} \mathrm{KI}$ cell line; (2) $\mathrm{CHO} \mathrm{TK}^{-} \mathrm{MT}^{-}$ derivative; (3) $\mathrm{TK}^{-}$tsm strain; (4) and (5) $\mathrm{TK}^{-}$cells selected after treatment of (2) with 5-Aza-CR and 5-Aza-CdR, respectively; (6) and (7) $\mathrm{TK}^{+}$cells selected after treatment of (2) with 5-Aza-CR and 5-Aza-CdR, respectively; $(8) \mathrm{TK}^{+}$derivative selected after treatment of $(3)$ at $39^{\circ} \mathrm{C}$; (9), (10), and (11) $\mathrm{TK}^{-}$ clones spontaneously deriving from (6), (7), and (8), respectively. Samples were digested with HindIII/HhaI and electrophoresed in a $0.8 \%$ agarose gel and blotted. This blot was hybridized to the ${ }^{32} \mathrm{P}$-labeled 5.5-kb genomic fragment (Fig. 3a).

specific demethylation in $\mathrm{TK}^{+}$revertant clones (Figs. 5 and 6 , lanes $6-8)$. In all the parent strains, a $4.2-\mathrm{kb}$ EcoRI DNA fragment was detected for both HpaII (Fig. 5, band a, lanes 1-3) and HhaI (Fig. 6, band a, lanes 1-3) digestions. This fragment is of identical size to the band detected in CHO KI DNA digested only with EcoRI (Fig. 5 , band a, lane $1 E$ ), and it probably represents a copy of the TK gene completely methylated in this region. A similar size restriction fragment was detected in HindIII-digested DNA (Fig. 5, band e, lanes 1-3; Fig. 6, band e, lanes 1-3). The additional lower-molecular-weight bands (Fig. 5, bands $\mathrm{d}$ and $\mathrm{h}$ ) in the HpaII blots may then be an undermethylated allele. However, complete demethylation of the $4.2-\mathrm{kb}$ fragment should create much smaller DNA fragments as revealed by $M s p I$ digestion (Fig. 5 and Lewis 1986), suggesting that the second TK copy is not completely demethylated (see Discussion). Similarly, the two lower bands in the HhaI blots (Fig. 6, bands $b, c, f$, and $h$ ) may represent either two undermethylated copies of the $4.2-\mathrm{kb}$ fragment or population variability in the methylated state of one copy.

Reversion to the $\mathrm{TK}^{+}$phenotype is correlated with the loss of the 4.2-kb fully methylated fragments (Figs. 5 and 6 , bands a and e, lanes 6-8), indicating that demethylation has occurred. However, 5-Aza-CR- and 5-Aza-CdRtreated cells that retained the $\mathrm{TK}^{-}$phenotype show no such demethylation (Figs. 5 and 6, lanes 4 and 5), suggesting that a correlation exists between $\mathrm{TK}^{-}$to $\mathrm{TK}^{+}$ reversion and cytosine demethylation in this region of the gene. The detection of two partially demethylated HhaI-EcoRI or Hhal-HindIII restriction fragments (Fig. 6 , bands $b, c$ or $f, h$ ) suggests the presence of at least two HhaI sites susceptible to demethylation (Fig. 3c). Partial remethylation of the HhaI sites (Fig. 6, lanes 9, 10, 11, bands indicated with solid arrows; Fig. 3c, bands b, $\mathrm{c}$ or f, g) was detected upon backreversion from $\mathrm{TK}^{+}$to $\mathrm{TK}^{-}$ phenotype, indicating that changes in the level of methylation might be important for reversion of the phenotype. Additionally, the HpaII partially demethylated bands reproducibly showed size fluctuation in revertants to $\mathrm{TK}^{+}$phenotype (Fig. 5, bands $\mathrm{d}$ and $\mathrm{h}$, lanes, 6-8) and backrevertants to $\mathrm{TK}^{-}$phenotype (Fig. 5, bands $\mathrm{d}$ and $\mathrm{h}$, lanes 9-11). One explanation for this is the presence of more than one HpaII site in this region. Alternatively, fluctuation could be due to genetic mutations. The later suggestion is unlikely, since both $\mathrm{TK}^{+}$revertant and parent cell lines show the same $M s p I$ digestion patterns (Fig. 5).

Methylation changes were detected in the $4.2-\mathrm{kb}$ EcoRI fragment at both the HhaI and HpaII recognition sites. The bands, b-d in the EcoRI panels of Figures 5 and 6, lanes $6-8$, range between 3.5 and $3.7 \mathrm{~kb}$; the equivalent bands $\mathrm{f}-\mathrm{h}$ in lanes $6-8$ of the HindIII panels are approximately $200 \mathrm{bp}$ longer. The difference in the size of these bands between EcoRI and HindIII blots suggests that they result from HpaII or HhaI restriction of one of the ends of the EcoRI or HindIII fragments. Additionally, the detection of higher molecular weight fragments in the HindIII blots of $\mathrm{TK}^{+}$revertants (Figs. 5 and 6 , lanes 6-8) suggests that the demethylation may be located in an approximately 200 -bp region some $500 \mathrm{bp}$ downstream from the $5^{\prime}$ end of the $4.2-\mathrm{kb}$ fragment (diagramatically presented in Fig. 3c).

The methylation status of the MTI gene was also studied in $\mathrm{MT}^{-}\left(\mathrm{CHO} \mathrm{TK}^{-} \mathrm{MT}^{-}\right.$and tsm cells) and $\mathrm{MT}^{+}$clones induced either by 5-Aza-CR or treatment of the tsm strain at $39^{\circ} \mathrm{C}$. These DNAs were initially digested with EcoRI and then with either of the methylation-inhibited enzymes HpaII and HhaI or the methylation-insensitive isoschizomer of HpaII, MspI. The products were electrophoresed and transferred to nitrocellulose filters. Specific MTI fragments were then detected by hybridization of the filter with a 64-bp-long MTI cDNA probe covering the 3' untranslated part of the cDNA of the gene. This probe has only $37 \%$ homology to the MTII counterpart and would only detect MTI homologous sequences (Griffith et al. 1983; Crawford et al. 1985). Figure 7 shows that the probe hybrid- 
Gounari et al.

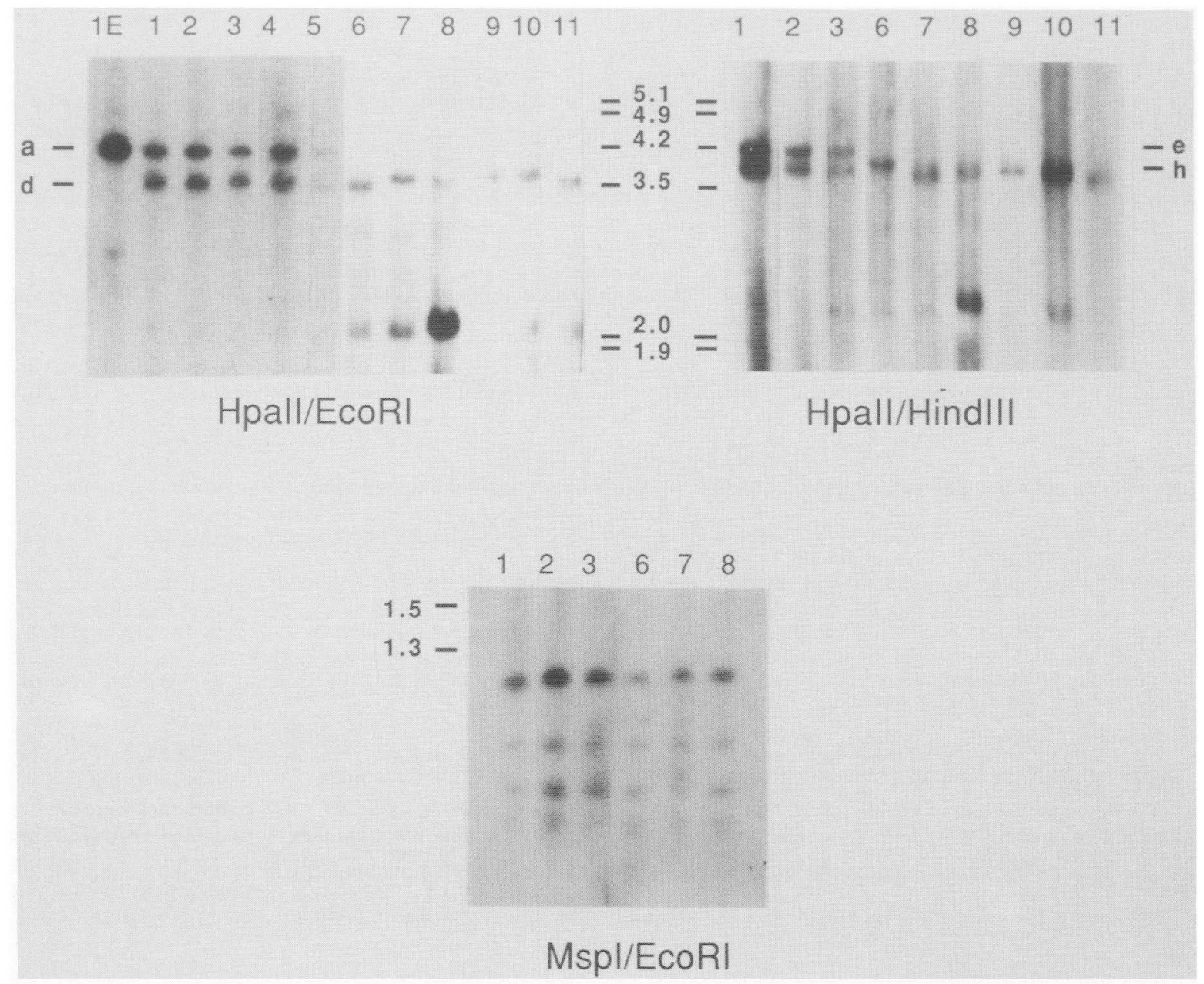

Figure 5. Methylation analysis of the HpaII sites of the 4.2-kb EcoRI-EcoRI fragment in the CHO KI cell line and its derivatives. DNA samples (15 $\mu \mathrm{g}$ per lane) were digested with either EcoRI/HpaII or HindIII/HpaII, electrophoresed through a $0.8 \%$ agarose gel in the numerical order described in Fig. 4, and blotted. Control digestion with MspI/EcoRI was also performed for the parent (lanes 1-3) and the $\mathrm{TK}^{+}$revertant clones (lanes 6-8). These blots were hybridized to the $4.2-\mathrm{kb}$ EcoRI-EcoRI genomic probe. Lane $1 E$ in the HpaII/EcoRI panel is CHO KI DNA digested only with EcoRI. The origin of the bands a, d, e, and h is interpreted in Fig. 3.

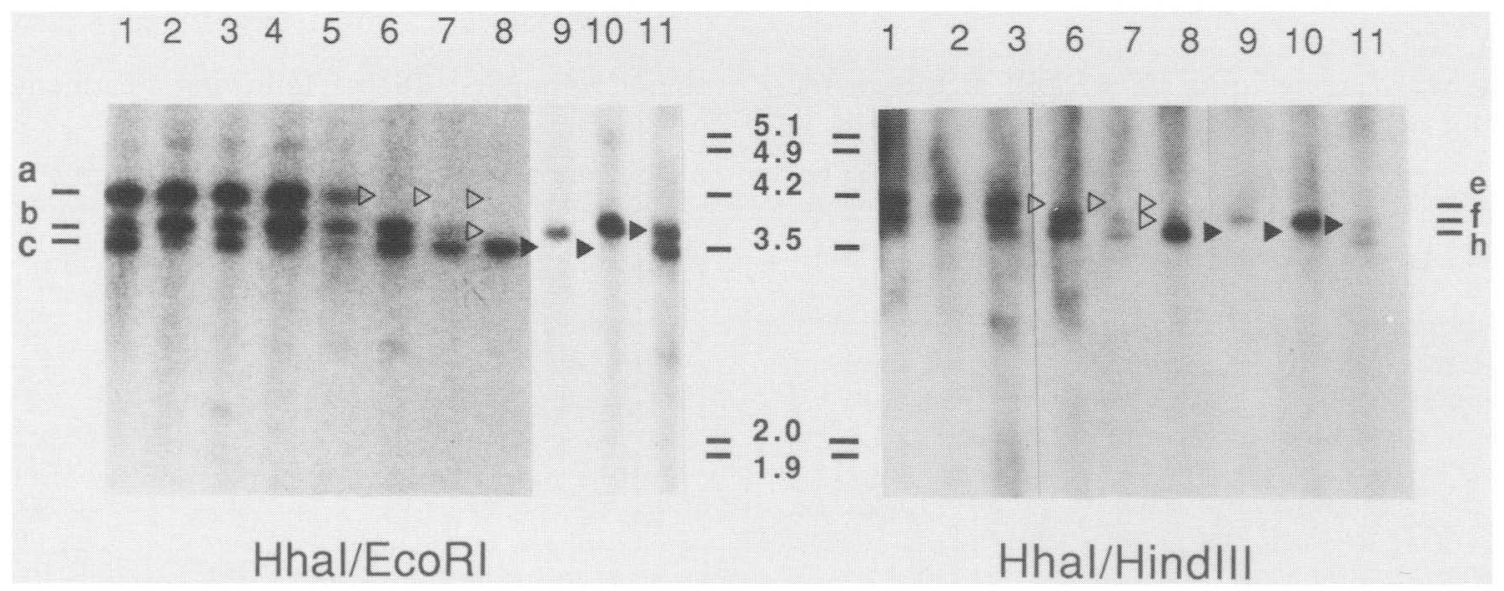

Figure 6. Methylation analysis of the $H$ haI sites of the 4.2-kb EcoRI-EcoRI fragment in the CHO KI cell line and its derivatives. DNA samples ( $15 \mu \mathrm{g}$ per lane) were digested with either EcoRI/HhaI or HindIII/HhaI, electrophoresed through a $0.8 \%$ agarose gel in the numerical order described in Fig. 4, and blotted. These blots were hybridized to the $4.2-\mathrm{kb} E c o \mathrm{RI}-E c o \mathrm{RI}$ genomic probe. The origin of the bands a, b, c, e, f, and $\mathrm{g}$ is interpreted in Fig. 3 . 


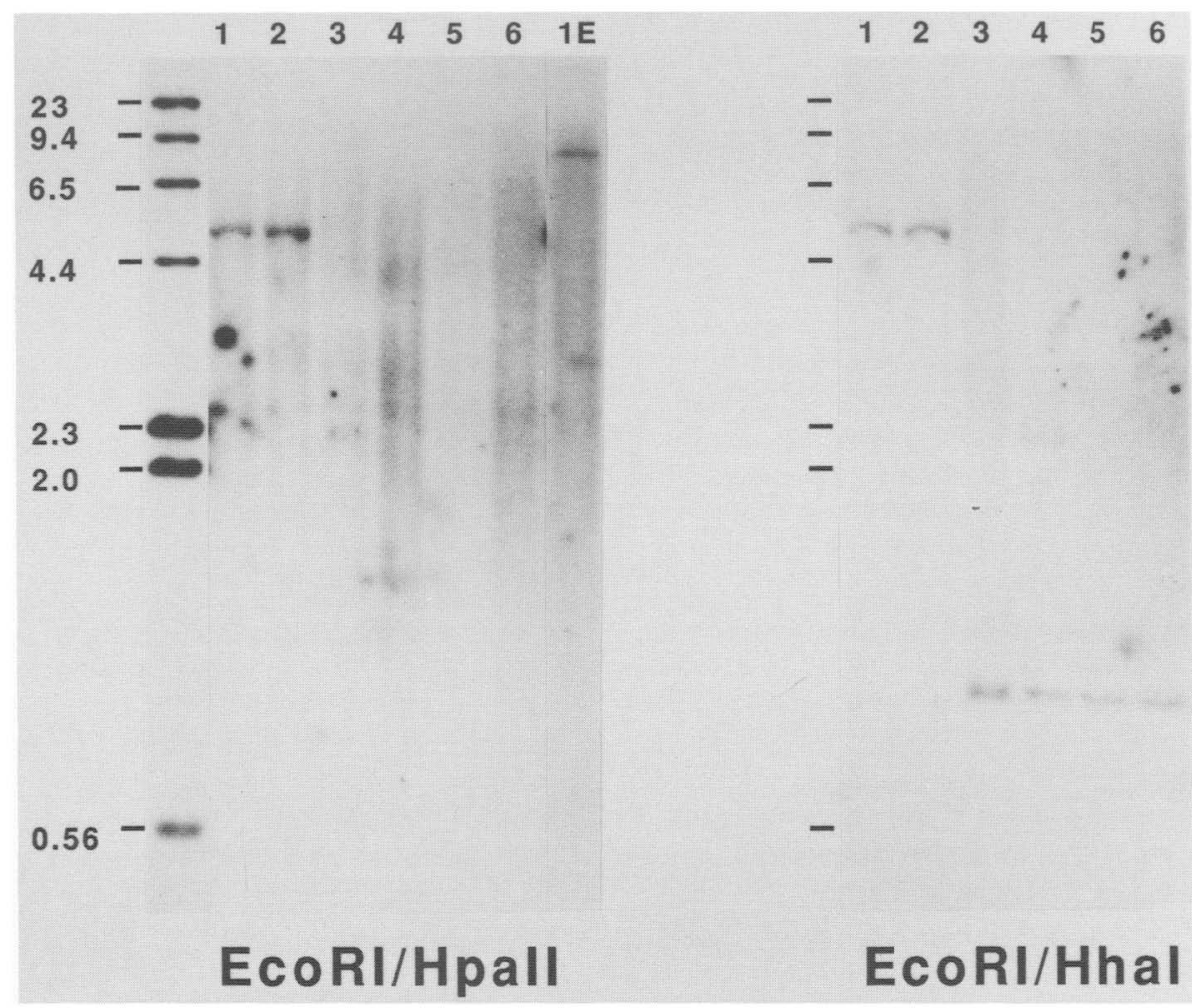

Figure 7. Methylation pattern of the MTI gene. DNAs from $\mathrm{CHO} \mathrm{TK}^{-} \mathrm{MT}^{-}, t s m$, and four $\mathrm{MT}^{+}$revertant clones were digested with EcoRI/MspI, EcoRI/HpaII, or EcoRI/HhaI and electrophoresed through a 1\% agarose gel. This was blotted onto a nitrocellulose filter that was hybridized against a 64-bp Chinese Hamster MTI-specific cDNA probe. Lanes 1 and 2 are CHO TK ${ }^{-} \mathrm{MT}^{-}$and tsm DNA, respectively. Lanes 3 are DNA from an $\mathrm{MT}^{+}$clone induced by 5-Aza-CR treatment, and lanes 4, 5, and 6 are DNAs from three different $t s m \mathrm{MT}^{+}$revertant clones. Lane $1 E$ is $\mathrm{CHO} \mathrm{TK}^{-} \mathrm{MT}^{-}$DNA digested only with EcoRI.

ized to a $5.2-\mathrm{kb}$ band in all the $\mathrm{TK}^{-}$cells (lanes 1 and 2 in EcoRI/HpaII and EcoRI/HhaI panels), which was approximately $3 \mathrm{~kb}$ shorter than the MTI homologous fragment resulting from single EcoRI digestion (lane $1 \mathrm{E}$ in EcoRI/HpaII panel). This indicates that HpaII and Hhal sites are already demethylated in the $\mathrm{MT}^{-}$clones.

None of the $\mathrm{MT}^{+}$revertants showed the $5.2-\mathrm{kb}$ band, indicating that demethylation had occurred (Fig. 7, panels EcoRI/HpaII, EcoRI/HhaI, lanes 3-6). An 0.8-kb fragment was detectable in $H h a \mathrm{I} / E$ coRI digests of the DNA from all $\mathrm{MT}^{+}$clones examined but not from $\mathrm{MT}^{-}$ cells (Fig. 7, panel EcoRI/Hhal, lanes 3-6).

\section{Discussion}

This report describes the application of a novel method for the isolation of a temperature-sensitive strain expressing alterations in DNA methylation. The $\mathrm{CHO}$ $\mathrm{TK}^{-} \mathrm{MT}^{-}$cell line was used for this purpose because evidence was available that the TK and MT genes in mouse, hamster, or human cells are under methylation control (Compere and Palmiter 1981; Harris 1982; Heguy et al. 1986; Stallings et al. 1986). The finding that 5-Aza-CR or 5-Aza-CdR caused $1-59 \%$ reversion to the $\mathrm{TK}^{+}$and $\mathrm{MT}^{+}$phenotype provided important evidence for such methylation control of TK and MT expression in $\mathrm{CHO} \mathrm{TK}^{-} \mathrm{MT}^{-}$cells. This evidence was supported by the specific demethylation of the genes detected by Southern blot analysis of reactivated clones and the demethylation observed by HPLC chromatography immediately after treatment. Our findings are in agreement with earlier observations on the demethylating effect of these agents (Jones and Taylor 1980, 1981; Wilson et al. 1983; Flatau et al. 1984).

5-Aza-CdR-treated cells that had lost $46 \%$ of their methylated cytosines showed no detectable remethylation for the first $10 \mathrm{cgs}$ following treatment. Subsequently (by approximately $50 \mathrm{cgs}$ ), the fraction of methylated cytosines had significantly increased, demonstrating the presence of de novo methylation activity. Surprisingly, some $150 \mathrm{cgs}$ after treatment, the DNA in $\mathrm{CHO}$ cells not only reached normal levels, but also gained up to $23 \%$ more methylation than that of untreated cells. Several previous reports showed that remethylation occurred in cells treated with $5-\mathrm{Aza}-\mathrm{CdR}$, but the efficiency of recovery varied between different cell lines (Compere and Palmiter 1981; Creusot et al. 1982; Gasson et al. 1983). In other studies it was shown that unmethylated cloned DNA introduced to cells in culture was eventually methylated (Clough et al. 1982; Hardies et al. 1983; Christy and Scangos 1984). However, none of these studies examined DNA remethylation for such an extensive period of growth as this report. 
The isolation of tsm was based on the assumption that temperature-dependent demethylation would result in reactivation of the TK and MT genes. The decision to search for a temperature-sensitive phenotype was based on the possibility that methylation deficiency might be lethal. The $t s m$ strain described here may have a recessive mutation at a functionally haploid locus (Siminovitch 1976; Jeggo and Holliday 1986) or possibly a dominant mutation. The phenotype is stable, and the strain was isolated at a frequency $(1 / 7000)$, comparable to mutations in the X-linked HPRT gene $(1 / 1000)$ after similar mutagenesis. The possibility that tsm is itself due to a change in DNA methylation is unlikely, since the temperature-sensitive phenotype indicates that it has an altered gene product rather than loss of gene expression. From the characteristics of tsm we assume it is due to a heritable mutation. Several observations defined the nature of the tsm mutation. Thus, induction at $39^{\circ} \mathrm{C}$ for at least one cell cycle resulted in reactivation of silent TK or MT genes at frequencies up to $1 / 1000$. Longer treatment at this temperature did not increase the level of phenotypic changes. tsm did not show increased mutation frequency at the HPRT locus. tsm $\mathrm{TK}^{+}$revertants showed high frequency of backreversion to $\mathrm{TK}^{-}$, these TK- backrevertants being reactivable by 5-Aza-CR, suggesting that $\mathrm{TK}^{-}$backreversion is probably due to de novo remethylation. Although our isolation procedure would allow the recovery of a conditional lethal mutation, tsm is in fact fully viable after long-term growth at $39^{\circ} \mathrm{C}$.

Phenotypic alterations resulting from temperature or from demethylation treatment were associated with changes in the transcriptional activity of the TK and MT genes. TK homologous RNA was detected by Northern hybridization in all cell lines. $\mathrm{TK}^{+}$revertant cells showed severalfold increase in the abundance of TK mRNA in comparison to the original $\mathrm{TK}^{+} \mathrm{CHO} \mathrm{KI}$ cells. This indicates that demethylation of the $\mathrm{TK}^{-}$strain results in not only reactivation, but also induction of the TK gene over and above the wild-type level. The presence of some TK mRNA in TK- cells could be explained by the detection of either the mitochondrial or a mutated cytosolic TK transcript. Northern hybridization revealed two MT homologous mRNA species in all cells, one of which corresponds in size to mature MT mRNA, and a larger molecule which may be either the product of an unidentified yet MT-like gene or an intermediate in the RNA processing of the MT transcript. The detection of MT transcripts even in $\mathrm{MT}^{-}$strains is probably due to the expression of an MT gene homologous to MTI but not inducible. The transcriptional activity of this gene may not be sufficient for survival in the concentration of $\mathrm{Cd}$ in the medium used in these experiments. Low levels of MT mRNA were also detected in $\mathrm{MT}^{-} \mathrm{HeLa}$ cells (Heguy et al. 1986). The $\mathrm{MT}^{+}$ clones showed severalfold increase in the levels of $M T$ transcript, probably due to activation of an inducible MT gene.

Although demethylation in the tsm was below the sensitivity of detection by HPLC analysis, specific changes in the pattern of DNA methylation were demonstrated by restriction analysis in tsm revertant clones. Additionally, like $\mathrm{TK}^{+}$cells resulting from 5-Aza-CdR treatment, tsm $\mathrm{TK}^{+}$revertant cells induced at $39^{\circ} \mathrm{C}$ showed a gradual increase in their methylation levels resulting in $60 \%$ higher methylation than the parent $t s m$. $\mathrm{TK}^{-}$cells when grown for about $150 \mathrm{cgs}$ after incubation at $39^{\circ} \mathrm{C}$. These tsm $\mathrm{TK}^{+}$cells showed $4.5 \% 5 \mathrm{mC}$ content, which implies that over $90 \%$ of their $\mathrm{CpG}$ doublets are methylated since $\mathrm{CpG}$ occurs in the mammalian genome five times less frequently than expected (Russell et al. 1976).

The availability of a series of CHO TK genomic probes (Lewis et al. 1983; Lewis 1986) facilitated a detailed analysis of the role of methylation in the expression of this gene. Demethylation in a region near the third exon was consistently observed in all $\mathrm{TK}^{+}$cell lines analyzed irrespective of their mode of generation from $\mathrm{TK}^{-}$cells. Thus, at least one HpaII and two HhaI sites at the upstream end of the 4.2-kb EcoRI fragment were always unmethylated in $\mathrm{TK}^{+}$cells, but methylated in the parental $\mathrm{TK}^{-}$cell line. The detection of a 2 -kb band in $\mathrm{TK}^{+}$revertants of the HpaII blots (Fig. 5, lanes 6-8) may also indicate demethylation of a HpaII site in the middle of the $4.2-\mathrm{kb}$ fragment. Interestingly, the 5 ' promoter region did not show any detectable epigenetic changes associated with the phenotype. This may result from the screening procedure, which would not detect DNA fragments smaller than $300 \mathrm{bp}$, or it may be that methylation in this area does not influence expression in our cell line. HpaII and HhaI restriction sites in the rest of the gene are completely methylated in all cell lines, suggesting that they are not involved in the control of TK gene expression.

The sites whose methylation status is correlated with TK gene activity may, however, cooperate with other sites that are not detectable in the present experiments and form a cluster within the $4.2-\mathrm{kb}$ EcoRI fragment. Support for this suggestion arises from the observed fluctuation in the size of the HpaIl band detected in $\mathrm{TK}^{+}$ revertants. Additionally, it should be borne in mind that HpaII and HhaI sites can detect less than $16 \%$ of the methylatable CpG doublets in the genome. Thus, these other sites either may be too close to be defined clearly or may not be detectable by HpaII or HhaI. However, the fact that detected epigenetic alterations associated with TK gene activation are identical when brought about by 5-Aza-CR, 5-Aza-CdR, and temperature increase in the tsm strain suggests that they are important in regulating TK gene expression.

Remethylation of HhaI sequences within the region identified above was found in all the $\mathrm{TK}^{+}$to $\mathrm{TK}^{-}$ backrevertants. These $\mathrm{TK}^{-}$backrevertants, in turn, generated $\mathrm{TK}^{+}$clones at high frequencies with 5-Aza-CR, an observation consistent with methylation being important in the generation of backrevertants. Remethylation, however, was never $100 \%$. Thus, the relative level of methylation may determine the phenotype, rather than the absolute modification status of specific nucleotides. Such a situation has been reported for the regula- 
tion of $\gamma$-globin gene expression (Murray and Grosveld 1985).

Although promoter sequences have been shown to confer methylation control on several eukaryotic and viral genes (Busslinger et al. 1983; Kruczek and Doerfler 1982; Stein et al. 1982; Langner et al. 1984), the present work strongly indicates that methylation of specific internal sequences can also control TK gene expression in $\mathrm{CHO}$ cells. This agrees with reports that methylation of either promoter or internal gene sequences is sufficient for inactivation of the herpes TK gene expression (Christy and Scangos 1984; Keshet et al. 1985).

The demethylation of DNA observed in all $\mathrm{MT}^{+}$ clones could not be studied in the same detail as for the TK gene because genomic probes were not available, and only a 64-bp MTI-specific cDNA probe could be used. However, demethylation must have occurred in these cells because the detectable HpaII and HhaI sites were found to be unmethylated after, but not before reversion to the $\mathrm{MT}^{+}$phenotype. These findings agree with previous reports on the regulation of the mouse MTI gene in which demethylation of HpaII sites was associated with its expression (Compere and Palmiter 1981). The $5.2-\mathrm{kb}$ band in the $\mathrm{MT}^{-}$cells is an MTI-specific fragment not completely methylated, since it is smaller than the fragment detected in DNA digested only with EcoRI.

The phenotypic alterations and subsequent increase in the levels of methylation in the $t s m$ strain parallel those observed with demethylating agents and suggest that the tsm mutation affects DNA methylation. It is unlikely that $t s m$ is affected in general DNA methylation since if this were the case, $5 \mathrm{mC}$ would be expected to continually decline during growth at $39^{\circ} \mathrm{C}$. Instead, it is possible that it affects the methylation of sites critical for gene expression, at least for some loci. Recently, evidence has been published that some methylation sites at the HPRT locus are maintained more faithfully than others (Yen et al. 1986), and it is possible that tsm loses the ability to maintain similar sites at the TK and MT loci. However, the effect of temperature on the reactivation of these genes appears to operate over one generation, not continuously at $39^{\circ} \mathrm{C}$. tsm also has the surprising property of increasing de novo methylation during long-term growth after a $24-\mathrm{hr}$ treatment at $39^{\circ} \mathrm{C}$. This suggests that $t s m$ may be defective in the regulation of DNA methylation. A regulatory mutation might alter the dynamic state between maintenance and de novo methylation or possibly feedback between de novo and maintenance activities.

It was shown here, that it is feasible to isolate temperature-sensitive mutants affected in DNA methylation. The same procedure should lead to the isolation of a family of mutants affected in different steps of the DNA methylation pathway. The availability of such mutants would provide a powerful approach in studying both the regulation and the biological role of DNA methylation. Studies might be extended to a wide range of biological functions without the use of inhibitors such as demethylating agents or in vitro modified DNA molecules.

\section{Materials and methods}

Cell lines, medium, and selection conditions

The $\mathrm{CHO}^{-} \mathrm{TK}^{-}$cell line was isolated from $\mathrm{CHO} \mathrm{KI}$ cells after mutagenesis by ethylmethanesulfonate (EMS), followed by long-term growth in bromodeoxyuridine (BUdR). The CHO KI cells are spontaneously $\mathrm{MT}^{-}$. All cells were routinely grown in MEM (Gibco F15) from Gibco-Biocult Ltd, UK, supplemented with $10 \%$ (vol:vol) fetal calf serum inactivated by $1 \mathrm{hr}$ treatment at $56^{\circ} \mathrm{C}$, antibiotics (penicillin, $0.25 \mu \mathrm{g} / \mathrm{ml}$ glutamine, and MEM nonessential amino acids $\times 100,1 \%$ (Gibco Biocult Ltd, UK). $\mathrm{TK}^{+}$cells were selected in HAT medium (100 $\mu \mathrm{M}$ hypoxanthine, $4 \mu \mathrm{M}$ aminopterin, $16 \mu \mathrm{M}$ thymidine). Medium containing $400 \mu \mathrm{g} / \mathrm{ml} \mathrm{BUdR}$ was used to select cells expressing the TK- phenotype. Metallothionein-expressing cells were selected in $2 \mu \mathrm{M} \mathrm{CdCl}_{2}$. Hypoxanthine phosphoribosyltransferase (HPRT) inactivation was measured by plating in medium containing $2 \mu \mathrm{g} / \mathrm{ml}$ 6-thioguanine.

\section{Treatment with 5-Aza-CdR and 5-Aza-CR}

Cells $\left(5 \times 10^{4}\right)$ were seeded in $25-\mathrm{cm}^{2}$ plastic flasks and incubated for $48 \mathrm{hr}$. Appropriate concentrations of $1-\mathrm{mg} / \mathrm{ml}$ stocks of 5-Aza-CdR frozen at $-70^{\circ} \mathrm{C}$ (Sigma Chemical Company Ltd) or freshly prepared $0.1-\mathrm{mg} / \mathrm{ml}$ stocks of $5-A z a-C R$ were added to the growth medium for $24 \mathrm{hr}$. Then cells were media changed with drug-free medium, and allowed a recovery period before plating in selective medium, or they were subcultured in drugfree medium.

\section{Estimation of backreversion to $\mathrm{TK}^{-}$in $\mathrm{TK}^{+}$revertant cells}

The rate of spontaneous back reversion to the $\mathrm{TK}^{-}$phenotype was determined in $\mathrm{TK}^{+}$revertant clones using fluctuation analysis (Luria and Delbruck 1943; Lea and Coulson 1949). One hundred cells were seeded into each of $1025-\mathrm{ml}$ plastic flasks and incubated to an approximate number of $10^{5}$ cells per flask for $\mathrm{TK}^{+}$revertant clones induced by demethylating agents and of $5 \times 10^{5}$ cells per flask for $t s m \mathrm{TK}^{+}$revertants. Three-fifths of the total number of cells were seeded in each of three petri dishes in BUdR-containing medium. After 7-10 days, incubation plates were fixed, stained, and counted.

\section{Procedure for the isolation of methylation-deficient mutants}

CHO $\mathrm{TK}^{-} \mathrm{MT}^{-}$cells were mutagenized with $300 \mu \mathrm{g} / \mathrm{ml}$ EMS, which allows approximately $10 \%$ survival. Ampules of frozen mutagenized cells were thawed and grown to confluency. Five hundred cells were seeded into $90-\mathrm{mm}$ petri dishes in medium containing $400 \mu \mathrm{g} / \mathrm{ml} \mathrm{BUdR}$ and incubated for 7-8 days at $34^{\circ} \mathrm{C}$. This plating density gave approximately 100 colonies per dish, which were ringed with a marker pen at the underside of the plate. The growth medium was removed, and the cells were overlaid with $5 \mathrm{ml}$ of $0.5 \%$ soft agar as described by Jeggo and Kemp (1983). A further 1-day incubation period is required for the cells to become rounded and start growing into the agar. At this stage they could be transferred easily to two replicate multiwell plates containing $1.5 \mathrm{ml}$ of medium per well using the plastic tip of an automatic Gilson pipettor. This procedure resulted in the transfer of approximately $10^{3}$ cells per well. After $4 \mathrm{hr}$ incubation at $34^{\circ} \mathrm{C}$, plates were examined under a lowpower microscope, and if the average number of cells per well was approximately $10^{3}$, one plate of each replicate was shifted to $39^{\circ} \mathrm{C}$. Twenty-four hours later $15 \mu \mathrm{HAT}(\times 100)$ was added, and the plates were incubated at $34^{\circ} \mathrm{C}$. Any isolate that pro- 
duced HAT-resistant clones could be recovered from the untreated replica plate.

\section{Northern blot}

Two micrograms per lane poly(A)-tailed RNA, prepared as in Vennstrom and Bishop (1982), was electrophoresed through formaldehyde/agarose gels which were soaked for $60 \mathrm{~min}$ in $20 \times$ SSC, prior to blotting onto a nitrocellulose filter for 12-16 $\mathrm{hr}$ in the cold room. Filters were prehybridized for 4-6 hr at $42^{\circ} \mathrm{C}$ ( $3 \times$ SSC, $50 \%$ formamide, $0.1 \%$ SDS, $10 \times$ Denhardt's solution), and then transferred to $25 \mathrm{ml}$ of preheated hybridization solution containing probe labeled as in Feinberg and Vogelstein (1983) and $10 \%$ dextran sulfate. Hybridization was for $18-24 \mathrm{hr}$ in plastic boxes. Filters were then washed to the desired stringency, air-dried, and autoradiographed.

\section{HPLC analysis}

The HPLC procedure for nucleotide analysis was developed by Dr. T. Matsumura in the Genetics Division. A Waters Associates system with a cation column (Partisil SC $\times 10 \mathrm{u}$ Type F) was used. Approximately $15-40 \mu \mathrm{g}$ hydrolyzed DNA in $0.1 \mathrm{M}$ $\mathrm{HCl}$ was injected in the injection apparatus with a Hamilton microsyringe and eluted with $0.05 \mathrm{M} \mathrm{HCl}$ through the column. The absorbance of the eluted samples was detected by the absorbance detectors and recorded with a pen recorder at two scales of sensitivity $1-0.01$. This setting allowed detection of both $\mathrm{C}$ and $5 \mathrm{mC}$ from the same injected sample.

\section{Isolation and digestion of genomic DNA}

High-molecular-weight DNA from $\mathrm{CHO}$ cells was isolated as described by Jeffreys and Flavell (1977). Restriction enzymes were bought from Bethesda Research Laboratories, and the digestions were performed with the conditions recommended by the manufacturer, at a ratio of 3-4 units of enzyme per microgram of DNA.

\section{Southern blot}

Agarose gels to be blotted onto nitrocellulose filters were soaked in $0.1 \mathrm{M} \mathrm{HCl}$ for $20 \mathrm{~min}$. The DNA was denatured by treatment with $0.2 \mathrm{M} \mathrm{NaOH}, 1.5 \mathrm{M} \mathrm{NaCl}$ for $45 \mathrm{~min}$, and the gel was neutralized with $0.5 \mathrm{M}$ Tris (pH 7.5), $1.5 \mathrm{M} \mathrm{NaCl}$ for $45 \mathrm{~min}$ under constant agitation. The gel was blotted onto a nitrocellulose filter. Transfer was allowed to proceed for $12-16 \mathrm{hr}$ in the cold room. Nitrocellulose filters were prehybridized for $4-6 \mathrm{hr}$ at $65^{\circ} \mathrm{C}(3 \times \mathrm{SSC}, 0.1 \%$ SDS, $10 \times$ Denhardt's solution $)$, then they were transferred individually in hybridization solution that contained probe labeled as described in Feinberg and Vogelstein (1983) and 10\% dextran sulfate. When the probe contained repetitive sequences, the labeled fragment was pretreated as described in Sealey et al. (1985). Similarly, when plasmid DNA was used, the probe was pretreated as above using sonicated vector. Hybridization was for $16-24 \mathrm{hr}$ at $65^{\circ} \mathrm{C}$ in plastic boxes. The filters were then washed to the desired stringency, rinsed, air-dried, and autoradiographed.

\section{Acknowledgments}

We are grateful to Dr. Toshiharu Matsumura for initiating the HPLC analysis and for scientific advice and to Dr. Tom Kirkwood for invaluable discussions. We are indebted to Dr. John Lewis for providing us cloned cDNA and genomic sequences of the Chinese hamster TK gene, together with unpublished infor- mation, and to Dr. J.K. Griffith for kindly providing us with cloned Chinese hamster MT cDNA, and to Dr. Peter Searle for invaluable advice. F. Gounari was supported by a Greek State Scholarships Foundation studentship. K. Khazaie was supported by a Medical Research Council (UK) Recombinant Technology Training Fellowship.

\section{References}

Adair, G.M., J.H. Carver, and D.L. Wanders. 1980. Mutagenicity testing in mammalian cells. 1. Derivation of a Chinese Hamster Ovary cell line heterozygous for the adenine phosphoribosyltransferase and thymidine kinase loci. Mutat. Res. 72: 187-205.

Adams, R.L. and R.H. Burdon. 1985. The molecular biology of DNA methylation. Springer Verlag, New York.

Adams, R.L., E.L. McKay, L.M. Graig, and R.H. Burdon. 1979. Mouse DNA methylase: Methylation of native DNA. Biochim. Biophys. Acta 561: 345-357.

Barr, F.G. and M.W. Lieberman. 1987. A processed gene homologous to the thymidine kinase gene in Chinese Hamster cells. Nucleic Acids Res. 11: 4693.

Barr, F.G., S. Rajagopapalan, G.A. MacArthur, and M.W. Lieberman. 1986. Genomic hypomethylation and far-5' sequence alterations are associated with carcinogen-induced activation of the Hamster thymidine kinase gene. Mol. Cell. Biol. 6: 3023-3033.

Busslinger, M., J. Hurst, and R.A. Flavell. 1983. DNA methylation and the regulation of globin gene expression. Cell 34: 197-206.

Christy, B. and G.A. Scangos. 1982. Expression of transfected thymidine kinase genes is controlled by methylation. Proc. Natl. Acad. Sci. 79: 6299-6303.

.1984. Changes in the structure and the methylation pattern in a cluster of thymidine kinase genes. Mol. Cell. Biol. 4: $611-617$.

Clough, D.W., L.M. Kunkel, and R.L. Davidson. 1982. 5-Azacytidine induced reactivation of a Herpes Virus Thymidine Kinase gene. Science 216: 70-73.

Compere, S.J. and R.D. Palmiter. 1981. DNA methylation controls the inducibility of mouse MTI gene in lymphoid. Cell 25: 234-240.

Conklin, K.F., J.M. Coffin, H.L. Robinson, M. Groudine, and R. Eisenman. 1982. Role of methylation in the induced and spontaneous expression of the avian endogenous virus ev-1: DNA structure and gene products. Mol. Cell. Biol. 2: 638652.

Crawford, B.D., M.D. Enger, B.B Griffith, J.K. Griffith, J.L. Hanners, J.L. Longmire, A.C. Munk, R.L. Stallings, J.C. Tesmer, and R.A. Walters. 1985. Coordinate amplification of metallothionein I and II genes in cadmium-resistant Chinese hamster cells: Implications for mechanisms regulating metallothionein gene expression. Mol. Cell. Biol. 5:320329.

Creusot, F., G. Acs, and J. Christmann. 1982. Inhibition of DNA methyltransferase and induction of Friend erythroleukemia cell differentiation by 5-azacytidine and 5-aza-2deoxycytidine. J. Biol. Chem. 257:2041-2048.

Delers, A., J. Szpirer, C. Szpirer, and D. Saggioro. 1984. Spontaneous and 5-azacytidine induced reexpression of ornithine carbamoylase transferase in hepatoma cells. Mol. Cell. Biol. 4: $809-812$.

DeVries, P.J., R.L. Davidson, and D.W. Clough. 1986. Site specificity of DNA methylation and expression of Herpes Simplex Thymidine Kinase gene. Somatic Cell Mol. Genet. 12: $385-393$. 
Doerfler, W. 1983. DNA methylation and gene activity. Annu. Rev. Biochem. 52: 93-124.

Feinberg, A.P. and B. Vogelstein. 1983. Technique for radiolabeling DNA restriction endonuclease fragments to high specific activity. Anal. Biochem. 132: 6-13.

Flatau, E., F.A. Gonzales, L.A. Michalowsky, and P.A. Jones. 1984. DNA methylation in 5-Aza-2-deoxycytidine resistant variant of C3H 10T1/2 C18. Mol. Cell. Biol. 4: 2098-2102.

Gasson, J.C., T. Ryden, and S. Bourgeois. 1983. Role of de novo DNA methylation in the glucocorticoid resistance of $T$ lymphoid cell line. Nature 302: 621-632.

Goss, S.J. 1984. The associated reactivation of two X-linked genes: The spontaneous and 5-azacytidine induced re-expression of ornithine transcarbamoylase and glucose-6phosphate dehydrogenase in a rate hepatoma. I. Cell Sci. 72: $241-257$.

Griffith, B.B., R.A. Walters, M.D. Enger, C.E. Hildebrand, and J.K. Griffith. 1983. cDNA cloning and nucleotide sequence comparison of Chinese Hamster metallothionein I and II mRNAs. Nucleic Acids Res. 11: 901-910.

Groudine, M., R. Eisenman, and H. Weintraub. 1981. Chromatin structure of endogenous retroviral genes and activation by an inhibitor of DNA methylation. Nature 292: 311317.

Gruenbaum, Y., H. Stein, and A. Razin. 1982. Substrate and sequence specificity of eukaryotic DNA methylase. Nature 295: $620-622$.

Hardies, S.C., D.E. Axelrod, M.H. Edgell, and I.I. Hutchinson. 1983. Phenotypic variation: Associated with molecular alterations at a cluster of thymidine kinase genes. Mol. Cell. Biol. 3: 1163-1171.

Harris, M. 1982. Induction of thymidine kinase in an enzymedeficient Chinese Hamster cell. Cell 29: 483-492.

- 1984a. Variables inducible for glutamine synthetase in V79-56 cells. Somatic Cell Mol. Genet. 10: 275-281.

1984b. High frequency induction by 5 -azacytidine of proline independence in CHO KI cells. Somatic Cell Mol. Genet. 10: 615-624.

- 1986. Induction and reversion of asparagine auxotrophs in CHO-K1 and V79 cells. Somatic Cell Mol. Genet. 12: $459-466$.

Heguy, A., A. West, R.I. Richards, and M. Karin. 1986. Structure and tissue specific expression of the metallothionein I bgene. Mol. Cell. Biol. 6: 2149-2157.

Hickey, I., S. Jones, and L. O'Neill. 1986. 5-Azacytidine induces reversion of thymidine kinase deficiency in Friend erythroleukemia cells. Exp. Cell Res. 164: 251-255.

Holliday, R. and J.E. Pugh. 1975. DNA modification mechanisms and gene activity during development. Science 187: 226-232.

Ivarie, R.D. and J.A. Morris. 1982. Induction of prolactin deficient variants of $\mathrm{GH} 3$ rat pituitary tumor cells by ethyl methane sulfonate: Reversion by 5-azacytidine, a DNA methylation inhibitor. Proc. Natl. Acad. Sci. 79: 29672970.

-1986. Activation of a nonexpressed hypoxanthine phosphoribosyl transferase allele in mutant $\mathrm{H} 23 \mathrm{HeLa}$ cells by agents that inhibit DNa methylation. Mol. Cell. Biol. 6: $97-104$.

Jeffreys, A.J. and R.A. Flavell. 1977. Physical map of the DNA regions flanking the rabbit $\beta$-globin gene. Cell 12: 429-439.

Jeggo, P.A. and L.M. Kemp. 1983. X-ray sensitive mutants of CHO cell line. Isolation and cross sensitivity to other DNA damaging agents. Mutat. Res. 111: 313-327.

Jones, P.A. 1985. Altering gene expression with 5-azacytidine. Cell 40: 485-486.
Jones, P.A. and S.M. Taylor. 1980. Cellular differentiation, cytidine analogues and DNA methylation. Cell 20: 85-93.

- 1981. Hemimethylated duplex DNAs prepared from 5azacytidine treated cells. Nucleic Acid Res. 9: 2933-2947.

Keshet, I., J. Yisraeli, and H. Cedar. 1985. Effect of regional methylation on gene expression. Proc. Natl. Acad. Sci. 82: 2560-2564.

Kruczek, I. and W. Doerfler. 1982. The unmethylated state of the promoter/leader and 5 ' regions of integrated adenovirus genes correlates with gene expression. EMBO J. 4: 409-414.

Langner, K.D., L. Vardimon, D. Renz, and W. Doerfler. 1984. DNA methylation of three 5 '-CCGG-3' sites in the promoter and 5 ' region inactivate the E2A gene of adenovirus 2. Proc. Natl. Acad. Sci. 81: 2950-2954.

Lea, D.E. and C.A. Coulson. 1949. The distribution of the members of mutants in bacterial populations. I. Genet. 49: $264-285$.

Lewis, J.A. 1986. Structure and expression of the Chinese Hamster thymidine kinase gene. Mol. Cell. Biol. 6: 1459-1469.

Lewis, J.A., K. Shimizu, and D. Zipser. 1983. Isolation and preliminary characterisation of the Chinese Hamster Thymidine Kinase gene. Mol. Cell. Biol. 3: 1815-1823.

Lieberman, M.W., L.R. Beach, and R.D. Palmiter. 1983. Ultraviolet radiation-induced metallothionein-I gene activation is associated with extensive DNA demethylation. Cell 35: 207-214.

Liteplo, R.G., P. Frost, and R.S. Kerbel. 1984. 5-Azacytidine induction of thymidine kinase in a spontaneously enzyme deficient murine tumor line. Exp. Cell Res. 150: 499-504.

Lu, L.-J.W. and K. Randerath. 1980. Mechanism of 5-azacytidine-induced transfer RNA cytosine-5-methyltransferase deficiency. Cancer Res. 40: 2701-2705.

Luria, S.E. and M. Delbruck. 1943. Mutations in bacteria from virus sensitivity to virus resistance. Genetics 28: 491-511.

Murray, E. and F. Grosveld. 1985. Methylation and $\gamma$-globin expression. In Biochemistry and biology of DNA methylation, pp. 157-176. Alan R. Liss, New York.

Nakamura, N. and S. Okada. 1983. Mutations resistant to bromodeoxyuridine in mouse lymphoma cells selected by repeated exposure to EMS: Characterisation of phenotypic instability and reversion to HAT resistance by 5 -azacytidine. Mutat. Res. 111: 353-364.

Niwa, O. and T. Suguhura. 1981. 5-Azacytidine induction of mouse endogenous $C$ type virus and suppression of DNA methylation. Proc. Natl. Acad. Sci. 78: 6290-6294.

Puck, T., S. Ciecura, and A. Robinson. 1958. Genetics of somatic mammalian cells. III. Long term cultivation of euploid cells from human and animal subjects. Exp. Med. 108: $945-955$.

Razin, A., H. Cedar, and A. Riggs. 1984. DNA methylation: Biochemistry and biological significance. Springer Verlag, New York.

Riggs, A.D. 1975. X-inactivation differentiation and DNA methylation. Cytogenet. Cell Genet. 14: 9-25.

Roufa, D.J., B.N. Sadow, and C.T. Caskey. 1973. Derivation of $\mathrm{TK}^{-}$clones from revertant $\mathrm{TK}^{+}$mammalian cells. Genetics 75: 515-530.

Russell, G.J., P.M.B. Walker, R.A. Elton, and J.H. Subak-Sharpe. 1976. Doublet frequency analysis of fractionated vertebrate nuclear DNA. J. Mol. Biol. 108: 1-23.

Sealey, H.A., P.E. Whittaker, and E.M. Southern. 1985. Removal of repeated sequences from hybridisation probes. $\mathrm{Nu}$ cleic Acids Res. 13: 1905-1922.

Searle, S., A.F. Gillespie, D.J. Chiswell, and J.A. Wyke. 1984. Analysis of the variation in proviral cytosine methylation that accompanies transformation and morphological rever- 
sion in a line of Rous sarcoma virus infected Rat-1 cells. Nucleic Acids Res. 12: 5193-5210.

Siminovitch, L. 1976. On the nature of hereditable variation in cultured somatic cells. Cell 7: 1-11.

Simon, D., H. Stuhlmann, D. Jahner, H. Wagner, E. Werner, and R. Jaenisch. 1983. Retrovirus genomes methylated by mammalian but not bacterial methylase are not infectious. $\mathrm{Na}$ ture 304: 275-277.

Stallings, R.L., B.D. Crawford, R.A. Tobey, J. Tesmer, and C.E. Hildebrand. 1986. 5-Aza-CR induced conversion to cadmium resistance correlates with early $S$ phase replication of inactive metallothionein genes in synchronised $\mathrm{CHO}$ cells. Somatic Cell Mol. Genet. 12: 423-432.

Steglich, C., A. Greens, and I.E. Sheffler. 1985. Chinese Hamster cells deficient in ornithine decarboxylase activity: Reversion by gene amplification and 5-azacytidine treatment. Somatic Cell Mol. Genet. 11: 11-23.

Stein, R., A. Razin, and H. Cedar. 1982. In vitro methylation of the Hamster adenine phosphoribosyltransferase gene inhibits its expression in mouse L cells. Proc. Natl. Acad. Sci. 79: $3418-3422$.

Sugiyama, R.H., S.M. Arfin, and M. Harris. 1983. Properties of asparagine synthetase in asparagine independent variants of Jensen Rat Sarcoma cells induced by 5-azacytidine. Mol. Cell. Biol. 3:1937-1942.

Szybalski, W., E. Szylbaska, and G. Ragni. 1962. Genetic studies with human cell lines. Natl. Cancer Inst. Monogr. 7: 75-89.

Tsao, M.-S., K.G. Nelson, and J.W. Crisham. 1984. Biochemical effects of 12-O-tetradecamoyl-13-acetate, retinoic acid, phenolbarbitol, and 5-azacytidine on a normal rat liver epithelial cell line. J. Cell. Physiol. 121: 1-6.

Vennstrom, B. and J.M. Bishop. 1982. Isolation and characterisation of a chicken DNA homologous to the two putative oncogenes of avian erythroblastosis virus. Cell 28: 135-143.

Wilson, V.L., R.L. Momparlier, and P.A. Jones. 1983. Inhibition of DNA methylation by 5-azacytidine. Cancer Res. 43: 3493-3496.

Yen, P.H., T. Mohandas, and L.J. Shapiro. 1986. Stability of DNA methylation of the human hypoxanthinephosphoribosyltransferase gene. Somatic Cell Mol. Genet. 12: 153-161. 


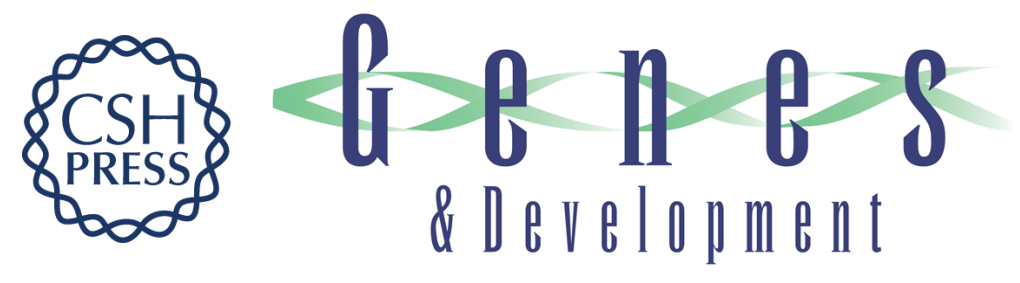

\section{Gene reactivation: a tool for the isolation of mammalian DNA methylation mutants.}

F Gounari, G R Banks, K Khazaie, et al.

Genes Dev. 1987, 1:

Access the most recent version at doi:10.1101/gad.1.9.899

$\begin{array}{ll}\text { References } & \text { This article cites } 66 \text { articles, } 25 \text { of which can be accessed free at: } \\ \text { http://genesdev.cshlp.org/content/1/9/899.full.html\#ref-list-1 }\end{array}$

License

Email Alerting Receive free email alerts when new articles cite this article - sign up in the box at the top Service right corner of the article or click here.

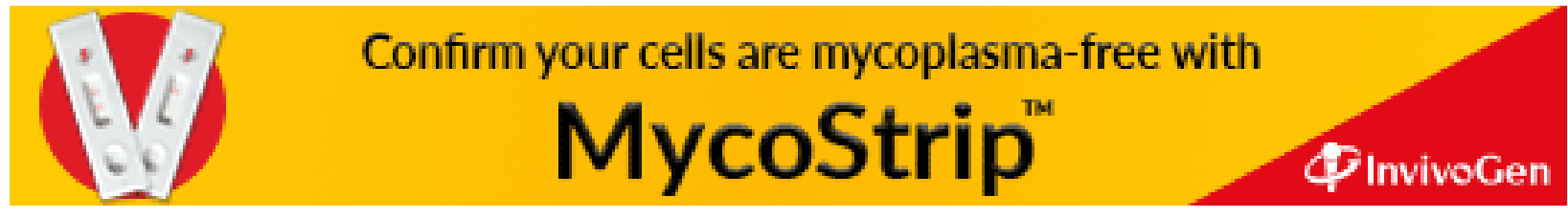

